Research Article

\title{
Planning of Hybrid Micro-Hydro and Solar Photovoltaic Systems for Rural Areas of Central Java, Indonesia
}

\author{
Ramadoni Syahputra $\mathbb{D}^{1}$ and Indah Soesanti $\mathbb{D}^{2}$ \\ ${ }^{1}$ Department of Electrical Engineering, Faculty of Engineering, Universitas Muhammadiyah Yogyakarta, \\ Yogyakarta 55183, Indonesia \\ ${ }^{2}$ Department of Electrical Engineering and Information Technology, Faculty of Engineering, Universitas Gadjah Mada, \\ Yogyakarta 55281, Indonesia \\ Correspondence should be addressed to Ramadoni Syahputra; ramadoni@umy.ac.id and Indah Soesanti;indahsoesanti@ugm.ac.id
}

Received 11 August 2019; Revised 1 December 2019; Accepted 24 December 2019; Published 21 January 2020

Academic Editor: Gorazd Stumberger

Copyright (c) 2020 Ramadoni Syahputra and Indah Soesanti. This is an open access article distributed under the Creative Commons Attribution License, which permits unrestricted use, distribution, and reproduction in any medium, provided the original work is properly cited.

\begin{abstract}
This paper proposes the planning of hybrid micro-hydro and solar photovoltaic system for rural areas of Central Java, Indonesia. The Indonesian government has paid great attention to the development of renewable energy sources, especially solar and hydropower. One area that has a high potential for both types of energy is the province of Central Java, located on the island of Java, Indonesia. In this research, we conduct field research to determine the ideal capacity of solar and micro-hydro hybrid power plants, electricity load analysis, and optimal design of hybrid power plants. Data on the potential of micro-hydro plants are obtained by direct measurement on the Ancol Bligo irrigation channel located in Bligo village, Ngluwar district, Magelang regency, Central Java province, Indonesia. Data on solar power potential were obtained from NASA's database for solar radiation in the Central Java region. Hydropower potential data include channel length, debit, heads, and power potential in irrigation channels originating from rivers. These data are used to design an optimal hybrid power plant. The method used to obtain the optimal design of a hybrid power plant system is based on the analysis of capital costs, grid sales, cost of energy, and net present cost. Based on the parameters of the analysis, the composition of the optimal generator for the on-grid scheme to the distribution network can be determined. The results showed that hybrid power plants were able to meet the needs of electrical energy in the villages around the power plant and that the excess energy could be sold to national electricity providers.
\end{abstract}

\section{Introduction}

At present, the power plants used in Indonesia, and even in the world, generally still use fossil fuel power plants, namely, coal and oil $[1,2]$. In Indonesia, until the end of 2017, power plants derived from fossil fuels amounted to $96 \%$ of the total national generating capacity [3]. The fossil fuel consists of $18 \%$ gas, $30 \%$ coal, and $48 \%$ oil. It is well known that fossil fuels will eventually run out because they cannot be renewed. Besides, air pollution, global warming, and climate anomalies are negative impacts resulting from the use of fossil fuel power plants. Based on these factors, a power plant that is derived from renewable energy sources is developed, for example, hydro, solar, geothermal, wind, biomass, and so on. The energy supply produced by renewable energy tends to be more environmentally friendly. However, it is necessary to increase technology and the willingness of various parties to make it happen, so that electricity costs become competitive compared to fossil energy $[4,5]$.

Indonesia, as a tropical country located on the equator, has renewable energy sources, namely, hydro, solar, geothermal, wind, bioenergy, and ocean currents. The total energy potential reached $441.7 \mathrm{GW}$ and and realized only $8.89 \mathrm{GW}$ until 2018 . The potential of hydro energy reaches $75 \mathrm{GW}(16.98 \%$ of the total renewable energy potential) [3], and that has been realized from the hydroelectric power plant reaching $5.124 \mathrm{GW}$. Meanwhile, the utilization of solar energy through solar power plants is still at $94.42 \mathrm{MWp}$.

Central Java province, located on Java island, Indonesia, geographically has the potential of hydro and solar energies, 
which is very potential to be developed. The potential of micro-hydropower plants in the province of Central Java, Indonesia, is $75,926 \mathrm{~kW}$. From this, the potential of microhydro plants that have been utilized is $69,832 \mathrm{~kW}$ or $92 \%$ of the existing potential [6]. Meanwhile, there is still $8 \%$ of untapped micro-hydro potential. The electrification ratio in Central Java province in 2018 has reached $85.29 \%$, so that efforts are still needed to be able to meet the electrical energy needs of the community, primarily through the construction of micro-hydropower plants and solar power.

Based on these potential data, it is necessary to develop and realize power plants from renewable energy sources, especially solar and hydro, as a provider of electrical energy for regions in Central Java. This research aims to design the most optimal model of hybrid power plants derived from solar and hydropower which is connected to the existing electricity grid. Analysis of generation costs and sales costs is an essential issue in the discussion of this study.

The location of this research is the Ancol Bligo irrigation channel located in Bligo village, Ngluwar district, Magelang regency, Central Java province, Indonesia. The potential of the hydro energy analyzed comes from irrigation channels that have relatively low heads but whose hydro flow tends to be stable. This stable irrigation channel is because the hydro energy comes from the Progo river, one of the largest rivers on the island of Java. The irrigation channel so far has only been used to flow through rice fields in Central Java and Yogyakarta Special Region provinces. In addition to hydro energy, this research also considered the potential of solar energy, because its potential is abundant. Indonesia is blessed with a strategic position from a renewable energy perspective because the equator crosses it. This position makes all regions of Indonesia receive sunlight throughout the year. The potential of these two energy sources, namely, hydro and solar, is exciting to be designed as an optimal hybrid power plant. These factors are the novelty of this research. Analysis of optimal hybrid power plant planning includes power capacity, grid sales, cost of energy, net present cost, and sale of electricity.

Studies on the planning and application of renewable energy power plants have been carried out in [7, 8]. In [7], the adaptive sliding mode control of a single-phase microgrid system to improve the power quality of the standalone microgrid power system has been carried out. The microgrid system integrates micro-hydropower plants, wind power plants, and solar power plants. These renewable energy power plants are integrated using a single-phase voltage source converter. In order to maintain the energy balance between power plants, sliding mode control is used to estimate the real power of reference from the system so that the frequency can be controlled.

Kusaka et al. [8] have investigated the possibility of using a hybrid electric power generation system consisting of micro-hydro and solar PV that stands alone. The application of this hybrid power plant is for low-cost electricity production so that it can meet the electrical energy needs in typical remote and isolated rural areas. In this study, optimization of the technical and economic performance of the hybrid power system was determined based on the needs of electricity, solar and hydro resources, and the importance of continuity of electricity supply. Capital costs in the form of hybrid power plant installations and system operating costs are optimized using HOMER software based on hydro and solar resources and other possibilities, namely, grid extension and diesel power plants.

This research is particularly useful for people in the province of Central Java, Indonesia. In this area, until now, the potential of hydro and solar power has not been utilized optimally. The Ancol Bligo irrigation channel, which is part of the Mataram Ditch, has high historical value and is inherent in the people of Yogyakarta and Central Java, Indonesia. This irrigation channel was built in the 1940s, which was the preindependence era of the Republic of Indonesia. With the importance of this irrigation channel, it is believed its existence will continue to be maintained by the government and the community. The equator crosses the entire territory of Indonesia, so it has high solar energy potential. The location of this research is the western region of Indonesia. The western region of Indonesia has a distribution of solar radiation of around $4.5 \mathrm{kWh} / \mathrm{m}^{2} /$ day, with a monthly variation of $10 \%$. It is also hoped that this research is expected to intensify the use of renewable energy sources in Indonesia because it will have an impact on improving the economic conditions of the people and the government.

The development challenges discussed in this study are the issue of fossil fuels, which are increasingly depleted, as well as environmental issues. An alternative solution offered is the use of power plants that originate from potential renewable energy sources on a massive scale. Two types of potential renewable energy power plants in Indonesia, especially in the central part of Java, where the study was conducted, are hydro and solar power plants. This research is expected to be more convincing to the Government of Indonesia to be more confident and have a high commitment to developing potential renewable energy sources. This effort is a form of dedication from academics who are also researchers for sustainable community development.

\section{Hybrid Solar-Hydro Power Plants}

Hybrid power generation is defined as a power generation system that combines two or more plants with different energy sources [9-11]. These generators are generally used for isolated grids, so those synergies are obtained which provide economic and technical advantages. The basic configuration of the hybrid power generation system can be grouped into three parts, namely, a series hybrid system, a parallel hybrid system, and a hybrid switched system $[12,13]$. In this study, the hybrid power plant discussed is a renewable energy power plant that comes from solar and hydropower. The configuration applied is a parallel hybrid system because it has advantages in continuity and is not dependent on each other. Solar and hydro hybrid power plant configurations are shown in Figure 1.

2.1. Micro-Hydro Power Plant. The hydroelectric power plant is a producer of renewable energy that is pollution-free 


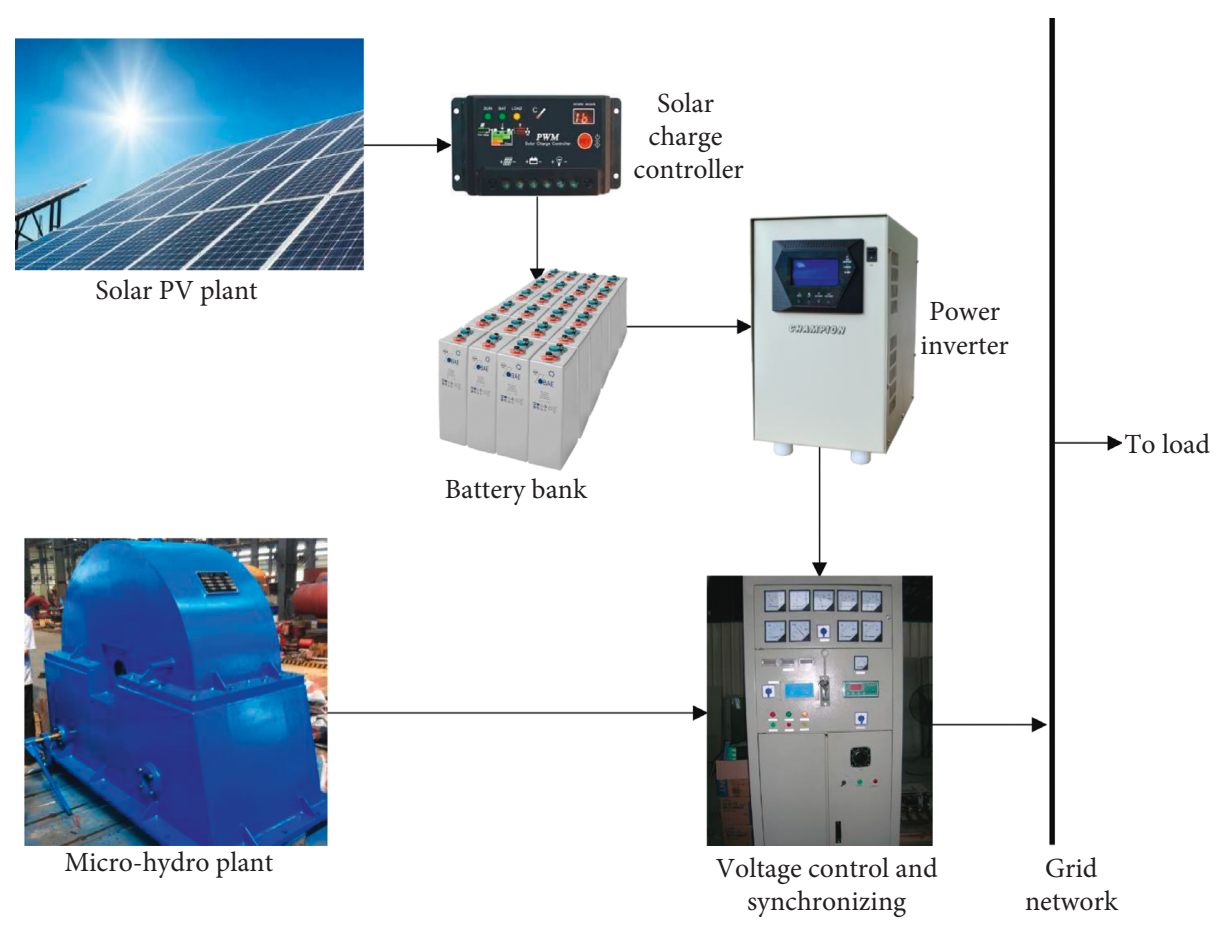

Figure 1: Solar and hydro hybrid power plant configurations.

and environmentally friendly [14]. The plant converts the kinetic energy of water to produce mechanical energy in the form of a hydro turbine spin, which is then used to turn a generator to produce electrical energy. Hydropower is the oldest energy conversion technology in the world [15]. Small-scale hydropower began to be used in general since the early 20th century. The first use of hydroelectric technology was for a waterwheel in the Fox River in Wisconsin in 1882 for two paper mills and households [16]. Based on the amount of power output, hydropower is classified as in Table 1.

Micro-hydropower has a scale power lower than $100 \mathrm{~kW}$. The condition of the hydro that can be utilized as an electricity-producing resource is that which has a particular flow and height capacity because electricity generated by micro-hydropower is also very dependent on the height of the waterfall and hydro discharge [17]. The higher the flow capacity and height from the installation, the higher the electrical energy that can be generated. The potential of micro-hydro energy in irrigation channels shows the ability of hydro flow in irrigation channels to produce electrical energy using hydroelectric technology. Electrical energy from the micro-hydro plant with a power range of 5-100 kW can be used to drive irrigation pumps, agricultural and rural activities, workshops, agricultural equipment, education, and others, which can increase population income and the ability and expertise of the community.

The power that can be generated from a micro-hydropower plant is very dependent on the size of the head and hydro discharge. Head is the difference in height between the level of hydro in the reservoir and the level of hydro that comes out of the hydro turbine. Micro-hydro energy potential can be calculated using the following equation:
TABle 1: Classification of hydropower plants based on power capacity [16].

\begin{tabular}{lc}
\hline Hydropower scheme & Power capacity \\
\hline Large hydro & $>100 \mathrm{MW}$ \\
Medium hydro & $15-100 \mathrm{MW}$ \\
Small hydro & $1-15 \mathrm{MW}$ \\
Mini hydro & $100 \mathrm{~kW}-1 \mathrm{MW}$ \\
Micro hydro & $5 \mathrm{~kW}-100 \mathrm{~kW}$ \\
Piko hydro & $<5 \mathrm{~kW}$ \\
\hline
\end{tabular}

$$
E=m \cdot g \cdot h,
$$

where $m$ is the hydro mass $(\mathrm{kg}), h$ is head of waterfall $(\mathrm{m})$, and $g$ is the gravitational constant $\left(\mathrm{m} / \mathrm{s}^{2}\right)$.

Hydro potential for electrical energy can also be obtained from low hydro flow, for example, from irrigation channels, as discussed in this study. The energy produced is kinetic energy, according to the following equation:

$$
E=\frac{1}{2} m v^{2},
$$

where $m$ is the hydro mass $(\mathrm{kg})$ and $v$ is hydro flow velocity $(\mathrm{m} / \mathrm{s})$.

Thus, the electrical power that can be generated by the micro-hydro plant can be calculated according to the following equation:

$$
P=\frac{1}{2} \rho A v^{3},
$$

where $\rho$ is the hydro density $\left(\mathrm{kg} / \mathrm{m}^{3}\right), A$ is cross-sectional area of hydro flow $\left(\mathrm{m}^{2}\right)$, and $v$ is hydro flow velocity $(\mathrm{m} / \mathrm{s})$. 
2.2. Solar Photovoltaic Power Plant. Solar energy is one of the energies currently being actively developed by the Government of Indonesia because, as a tropical country, Indonesia has sizeable solar energy potential. Based on the report of Indonesia Renewable Energy Prospects by the International Renewable Energy Agency (IRENA) [18], solar radiation data collected from 18 locations in Indonesia can be classified into two regions. The two regions are the western region of Indonesia with a distribution of around $4.5 \mathrm{kWh} / \mathrm{m}^{2} /$ day with a monthly variation of $10 \%$ and eastern Indonesia with a distribution of around $5.1 \mathrm{kWh} / \mathrm{m}^{2}$ / day with a monthly variation of around $9 \%$. Central Java province is a region that is included in the western region of Indonesia. Figure 2 shows the solar radiation map of the Indonesian area [19].

The International Renewable Energy Agency (IRENA) sincerely hopes that the Indonesian government has installed solar power plants that have grown significantly on a large scale by 2030 . In this case, the government has committed and encouraged its development by providing several initiatives through the Ministry of Energy and Mineral Resources, together with the state electricity company PLN. Based on IRENA estimates, Indonesia will use solar power with a capacity of up to $47 \mathrm{GW}$ by 2030 . This estimate is based on the 2017 Roadmap for the Future of Renewable Energy (REmap) program, as seen in Figure 3 [20].

When compared to conventional electricity, initially photovoltaic solar power plants seem complicated, expensive, and challenging to operate $[21,22]$. However, in more than a decade in several regions in Indonesia, photovoltaic solar power plants have been built. Now, this type of renewable energy generation is increasingly popular and has become a system that is easy to operate and reliable, and operational costs are increasingly competitive. Also, this type of plant is a technology that is clean, is not noisy, and does not pollute the environment [23].

Based on the installation system to the existing electricity network, photovoltaic systems are classified into two types, namely, on-grid systems and off-grid systems [24]. Off-grid systems are often referred to as standalone systems [25]. Offgrid photovoltaic systems are now widely applied in Indonesia, especially in remote areas that have not yet received electricity from state electricity companies [26]. However, on-grid photovoltaic systems have now been developed to support the national electricity supply [27]. Central Java province is one of the potential areas for developing solar power photovoltaic systems.

In its application, solar photovoltaic systems require a medium to store electricity, namely, a battery bank [28]. A battery bank is a series of batteries connected in series and parallel which are used to store electrical energy from solar cells in large capacities. The use of this battery bank is beneficial and efficient because, regardless of the intensity of sunlight, electrical energy can be stored in the battery, with the help of a load voltage controller called the solar charge controller. Furthermore, from the battery, electrical energy in the form of DC voltage must be converted into AC voltage using a power inverter so that consumers can use it. The installation of photovoltaic systems is shown in Figure 4.
As the photovoltaic system installation is shown in Figure 4, the main components needed are solar cell modules, solar charge controllers, battery banks, and power inverters [29]. Solar cells function to convert solar radiation into electrical energy directly. The final product of the photovoltaic solar cell module resembles a sheet of glass with a thickness of $6-8 \mathrm{~mm}$. The electrical energy produced is in the form of DC voltage. This DC electricity is stored in a battery bank. Because the DC voltage generated by the solar cell varies according to the intensity of sunlight, a voltage controller, the solar charge controller, is used to charge the battery bank. This battery bank then connected to the power inverter to convert the DC voltage to AC voltage according to the applicable voltage system. Usually, the power inverter is equipped with an $\mathrm{AC}$ voltage controller so that the output voltage of the inverter matches the nominal voltage of the system used by the electrical load to the consumer. The output from this inverter can also be on-grid to the electric power distribution network [30].

\section{Methodology}

3.1. Research Step. This research was conducted at the Ancol Bligo irrigation channel located in Bligo village, Ngluwar district, Magelang regency, Central Java province, Indonesia. The steps of this research include three stages, namely, field research to determine the ideal capacity of solar and microhydro hybrid power plants, electricity load analysis in the area around Bligo village, and optimal design of hybrid power plants. The geographical position of the location of this study is $7.684567^{\circ}$ South Latitude and $110.273186^{\circ}$ East Longitude, as shown in Figure 5.

The procedures applied in this study are shown in Figure 6. Stages of the implementation of this research include literature study, determination of hybrid power plants parameters, field data collection, electricity load survey data, measurement and calculation of solar and hydro potential data, hybrid system design, analysis of design of optimal hybrid power plants, and making research conclusions.

Hydro potential data in this study were obtained from a direct survey in the research location. The location of this study is the Ancol Bligo irrigation channel in Bligo village, Ngluwar district, Magelang regency, Central Java province, Indonesia. In this irrigation canal, discharge and head measurements are carried out to determine the capacity of the micro-hydro generator that can be designed. Furthermore, potential solar energy was obtained from radiation data at the study site. This solar radiation data come from NASA, which are surface meteorology and solar energy for the Magelang region, Central Java. Another essential parameter in this study is the electrical load data. These load data determine the amount of electrical energy that can be sold to on-grid systems. Electricity load data are obtained through a load survey in the research location in Bligo village, Ngluwar district, Magelang regency, Central Java province, Indonesia.

3.2. Hydro Energy Potential in Central Java Province, Indonesia. The study began with a survey of research sites in 

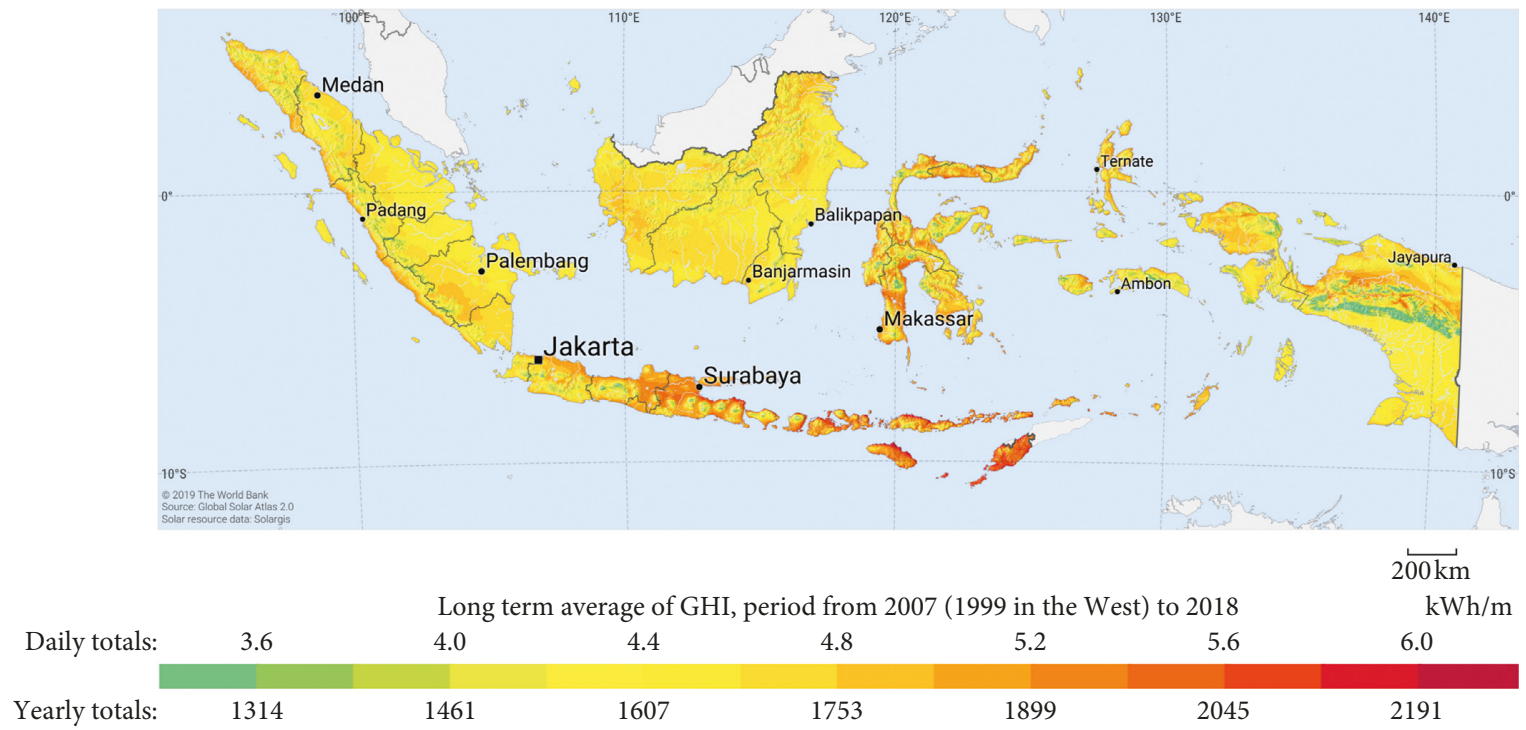

FIGURE 2: Solar radiation map of the Indonesian area [19].

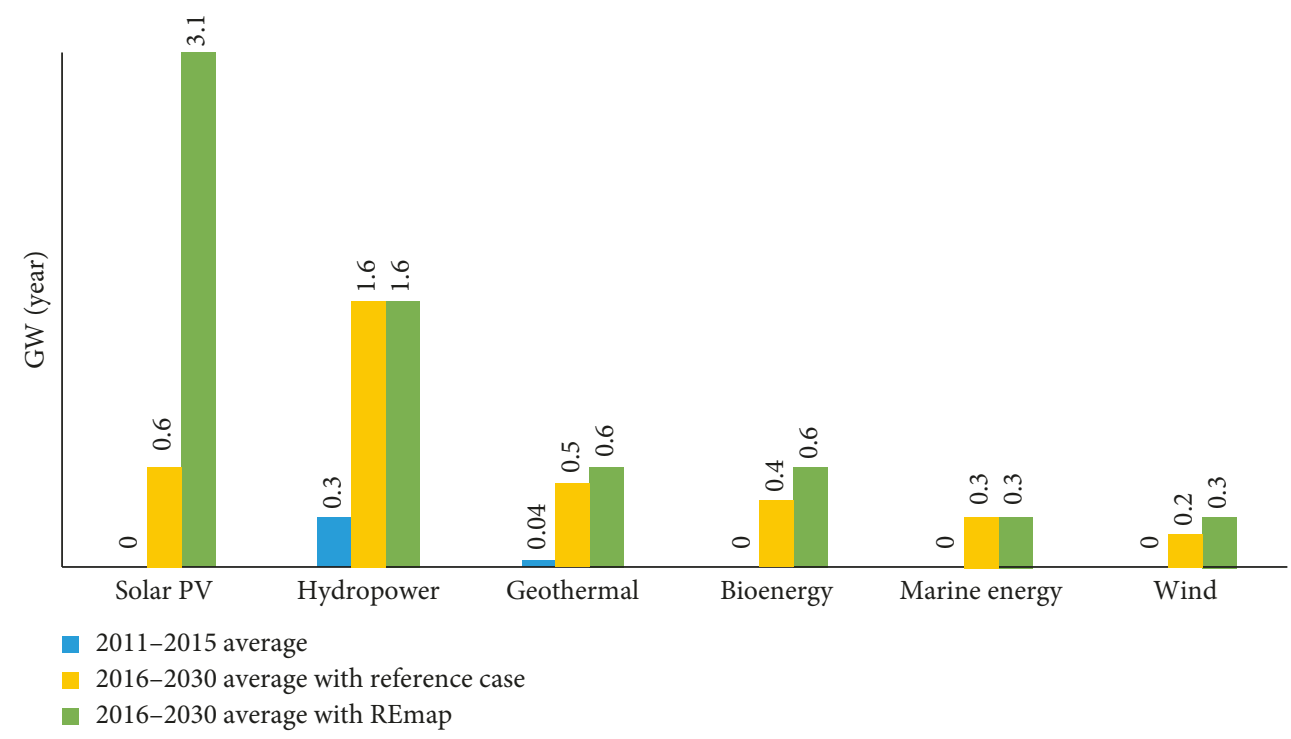

FIGURE 3: Annual renewable energy installations in 2011-2015 in the reference case of REmap for 2030 in Indonesia [20].

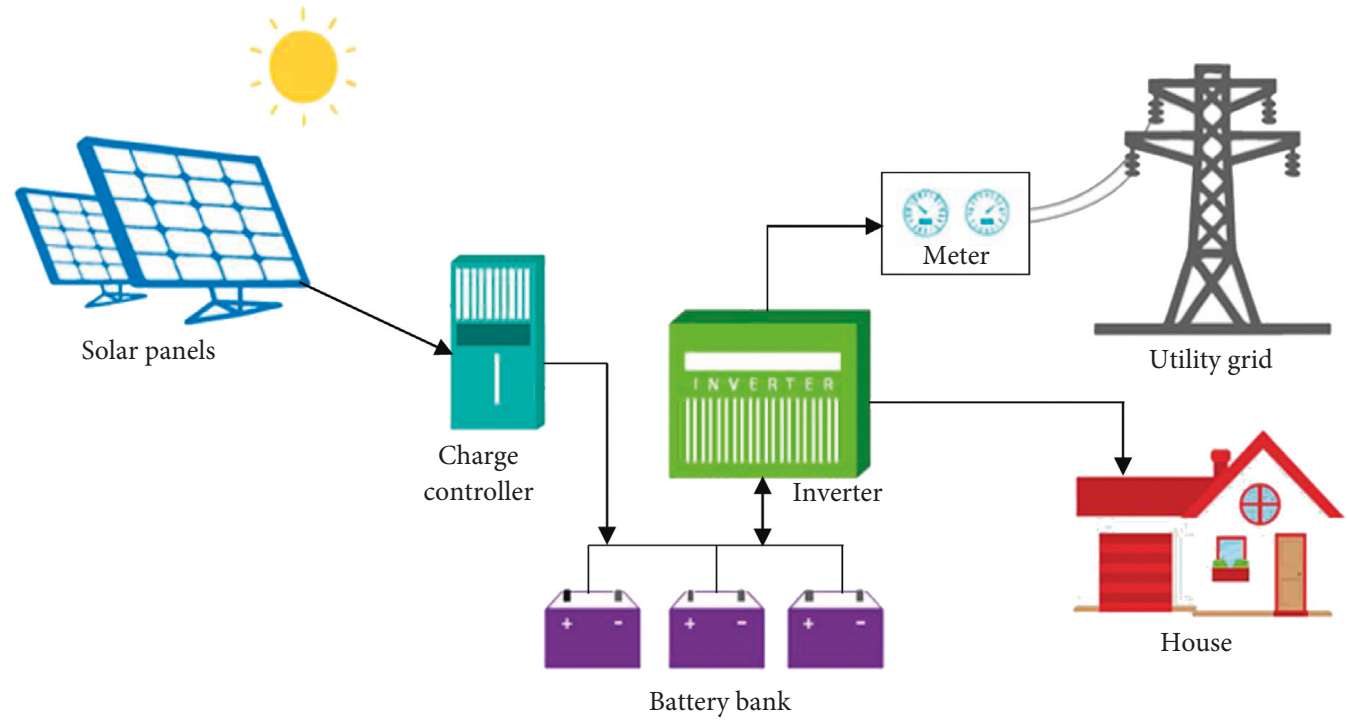

FIGURE 4: The installation of photovoltaic systems. 


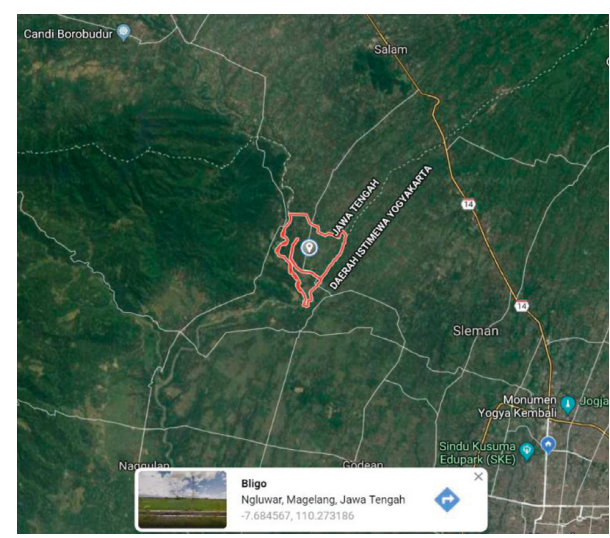

FIgURE 5: The geographical position of the location of this study.

the Ancol Bligo irrigation channel located in Bligo village, Ngluwar district, Magelang regency, Central Java province, Indonesia. In order to find out the potential of hydropower resources in this irrigation channel, head and hydro discharge measurements have been carried out to obtain the ideal micro-hydro generation capacity. This research was conducted from March to April 2019. The irrigation canal in Bligo village, Ngluwar district, Magelang regency, Central Java province, Indonesia, can be seen in Figures 7 and 8 .

The history of the Ancol Bligo irrigation channel is explained as follows. This irrigation channel is part of the Mataram Sewer, which was built during the Japanese government's control of the Indonesian territory, namely, in 1942-1945. At that time, the Japanese colonial government built an irrigation project known as "Mataram Ditch," or in Japanese, it was called "Yoshiro Canal." The construction of this canal was the result of an agreement between the Japanese colonial government and the King of the Ngayogyakarta Hadiningrat Sultanate at that time, namely, Sri Sultan Hamengkubuwono IX. The result of the agreement was that most of the population of Yogyakarta was allowed to work on making the Mataram Sewer irrigation channel. Thus the inhabitants of Yogyakarta were free from obligations as Japanese Romusha troops were sent outside Java. The construction of the irrigation canal is aimed at irrigating paddy fields around the Yogyakarta and Central Java regions. This irrigation channel is still functioning well, and its benefits are significant for the people of Yogyakarta and Central Java.

\section{Results and Discussion}

4.1. Electric Load Analysis. In this study, we report a survey of electricity loads in Bligo village, Ngluwar district, Magelang regency, Central Java province, Indonesia. Based on population data from the Central Statistics Agency of Magelang, in Bligo village, there are 1023 electricity customers for households. The data of 1023 electricity customers are used as a reference to which solar and micro-hydro hybrid power plants will supply electrical energy. The peak load in Bligo village is $337 \mathrm{~kW}$, which occurred in August.

The electricity loads in Bligo village, Ngluwar district, Magelang regency, Central Java province, Indonesia, can all be categorized as residential electricity loads. This fact is

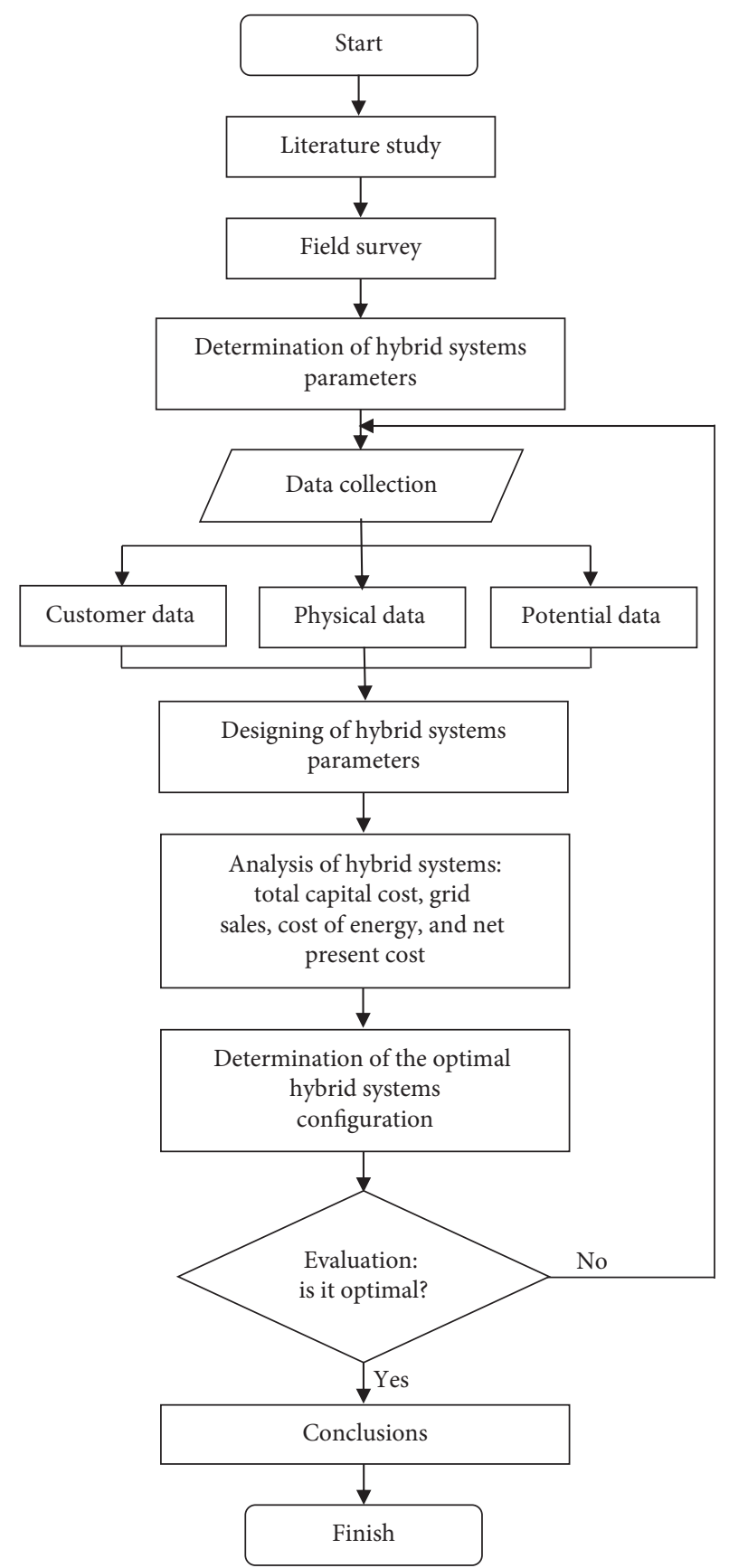

FIGURE 6: The procedures of this study.

because, in this village, there are no medium- and large-scale industries. The industries in this village are micro- and small-scale industries, where the use of electrical energy is the same as the household load, so it falls into the category of the household burden.

Electricity load profiles for tropical regions such as Indonesia can be considered the same for each month. This condition is due to the absence of extreme climate differences over one year. The seasonal load profile in this study is shown in Figure 9. Thus, the electric load profile, as shown in Figure 10, can be used to simulate the electricity load throughout the year. 


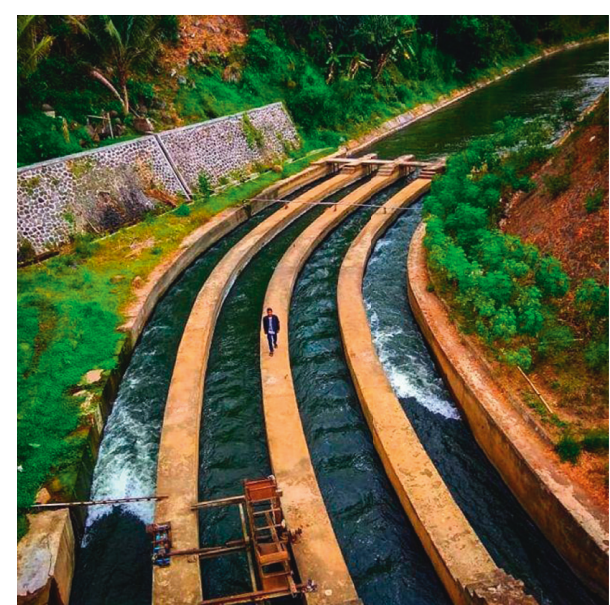

Figure 7: Irrigation canal in Bligo village, Ngluwar district, Magelang regency, Central Java province, Indonesia.

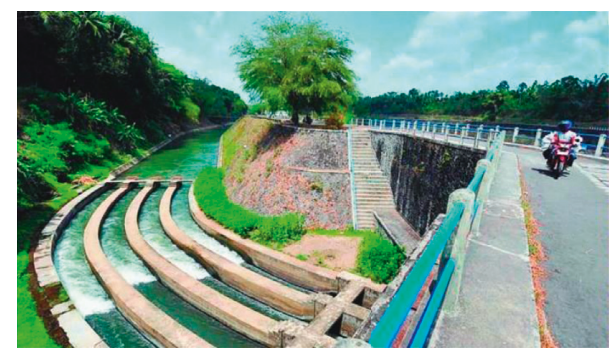

Figure 8: Another side view of irrigation canal in Bligo village, Ngluwar district, Magelang regency, Central Java province, Indonesia.

4.2. Design of Micro-Hydro System. In order to find out the Ancol Bligo irrigation channel debit, the following steps are carried out. The first step is to measure the width and depth of the irrigation channel using a meter. The second step is to measure the speed of the hydro using a small ball made of plastic. The ball is placed on the irrigation channel and washed away, and then the travel time along the $20 \mathrm{~m}$ on the surface of the irrigation channel is measured. Measuring is done using a stopwatch as much as 20 times in order to get accurate results. The irrigation canal measurement results obtained that the width of the irrigation channel is $10.5 \mathrm{~m}$ and the depth of the channel is $1.6 \mathrm{~m}$. The test results obtained by time, speed, and debit data are shown in Table 2 .

The next step is to calculate the potential capacity of micro-hydro power plants that can be built on the irrigation channel. The micro-hydro power capacity can be determined based on equation (3), where the irrigation channel head is $11.94 \mathrm{~m}$, the cross-sectional area of the irrigation channel is $16.8 \mathrm{~m}^{2}$, and the efficiency is $80 \%$. Based on these data, the capacity of micro-hydro power plants in the Ancol Bligo irrigation channel is $555 \mathrm{~kW}$.

Furthermore, Figure 11 shows the annual discharge and rainfall in Magelang, Central Java, Indonesia. These data were obtained from Open Data Pusdataru, Central Java province, Indonesia. This graph illustrates that fluctuating rainfall over a year does not significantly affect the flow of hydro in the Progo river. Progo river is the source of hydro from Ancol Bligo irrigation, which is the object of this research.

In designing micro-hydro power plants, preliminary data are required. These data are the cost of generating capital, replacement costs, operational and maintenance costs, a lifetime of the plant, hydro resource head, discharge, minimum and maximum flow, and turbine efficiency. Furthermore, these data are used as input for Homer application software, which will produce micro-hydro power generation capacity. Calculation results using Homer software show that the capacity of micro-hydro power is $555 \mathrm{~kW}$.

The micro-hydro system specifications to be applied in Bligo village, Ngluwar district, Magelang regency, Central Java province, Indonesia, are shown in Figure 12. From that figure, it can be seen that the capacity of micro-hydro power plants that can be produced from the Ancol Bligo irrigation channel located in Bligo village, Ngluwar district, Magelang regency, Central Java province, Indonesia, is $555 \mathrm{~kW}$. This micro-hydro capacity from Homer software is based on calculations using equation (3). Figure 12 also shows that the design of a micro-hydro generator uses a 3-phase AC generator.

The capital cost of a micro-hydro plant is US $\$ 1,132,426$, with a replacement cost of US $\$ 925,000$. The estimated operational and maintenance costs are US $\$ 53,219$, assuming that micro-hydro plants can be used for up to 100 years. This $555 \mathrm{~kW}$ capacity is also produced based on hydro potential data with $11.9 \mathrm{~m}$ head and a flow rate of $6,800 \mathrm{~L} / \mathrm{s}$. The minimum and maximum flow rates are $80 \%$ and $110 \%$, respectively, with $80 \%$ turbine efficiency. Based on the potential of the electric power generated by $555 \mathrm{~kW}$, the turbine used is the type of cross-flow PAT propeller, and the type of generator is a three-phase synchronous generator with a minimum efficiency of $80 \%$.

As shown in Figure 12 and the test results, and as shown in Table 2, the average flow rate of the Ancol Bligo irrigation channel, Magelang, Central Java, is 6,800 L/s. Complete monthly hydro flow rates in one year are shown in Figure 13 while Figure 14 shows details of flow rates of every month at the Ancol Bligo irrigation channel, Magelang, Central Java. This flow rate from year to year is relatively unchanged because the weather conditions in Indonesia are relatively stable. Figure 13 shows monthly hydro flow rates in one year at the Ancol Bligo irrigation canal, Magelang, Central Java. In contrast, details of flow rates every month at the Ancol Bligo irrigation canal, Magelang, Central Java, were shown in Figure 14.

\subsection{Design of Photovoltaic System}

4.3.1. Design of Photovoltaic Panel. The design of a photovoltaic power generation system in Homer software is shown in Figure 15. The figure shows that, for each photovoltaic panel with a $0.3 \mathrm{~kW}$ power capacity, the capital cost is US $\$ 500$, and the replacement cost is also US $\$ 500$. The size of the photovoltaic power plant capacity, which will be 


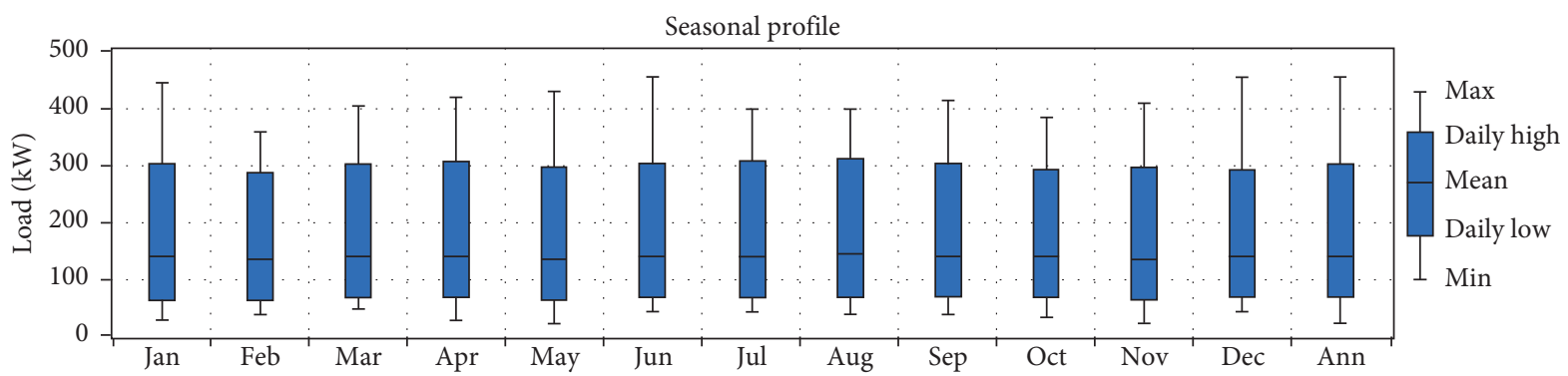

Figure 9: Seasonal load profile of each month in a year in Bligo village, central Java.

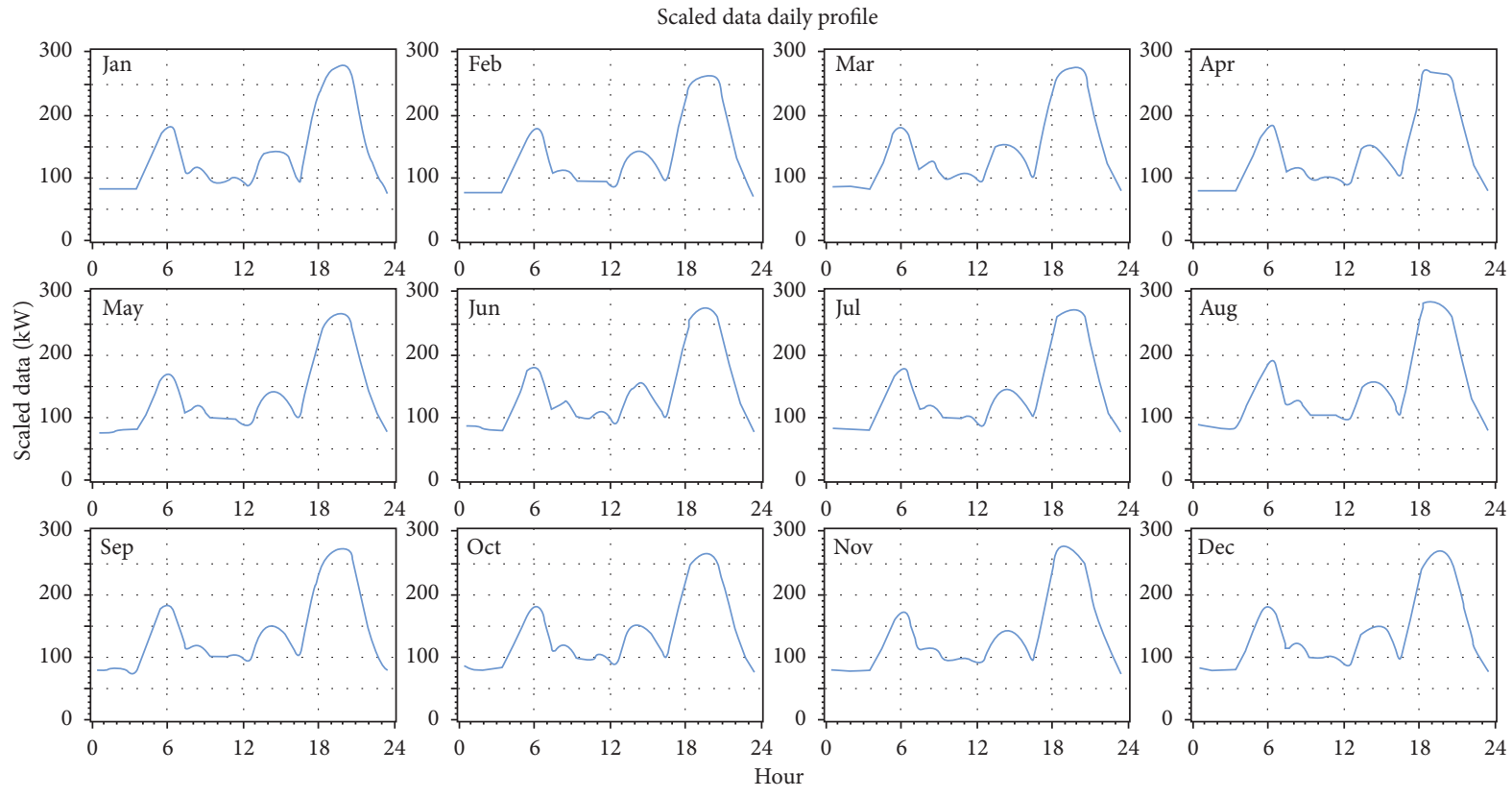

FIgURE 10: Hourly load profile for each month in a year.

TABLE 2: Testing results of Ancol Bligo irrigation channel.

\begin{tabular}{|c|c|c|c|c|c|c|}
\hline \multirow{2}{*}{ Testing numbers } & \multicolumn{3}{|c|}{ Examination in March 2019} & \multicolumn{3}{|c|}{ Examination in April 2019} \\
\hline & Time (s) & Velocity $(\mathrm{m} / \mathrm{s})$ & Debit $\left(\mathrm{m}^{3} / \mathrm{s}\right)$ & Time (s) & Velocity $(\mathrm{m} / \mathrm{s})$ & Debit $\left(\mathrm{m}^{3} / \mathrm{s}\right)$ \\
\hline 1 & 47.23 & 0.423 & 7.114 & 54.13 & 0.369 & 6.207 \\
\hline 2 & 48.82 & 0.410 & 6.882 & 53.15 & 0.376 & 6.322 \\
\hline 3 & 52.13 & 0.384 & 6.445 & 51.43 & 0.389 & 6.533 \\
\hline 4 & 51.19 & 0.391 & 6.564 & 51.55 & 0.388 & 6.518 \\
\hline 5 & 49.91 & 0.401 & 6.732 & 49.2 & 0.407 & 6.829 \\
\hline 6 & 47.72 & 0.419 & 7.041 & 49.19 & 0.407 & 6.831 \\
\hline 7 & 48.02 & 0.416 & 6.997 & 49.05 & 0.408 & 6.850 \\
\hline 8 & 46.3 & 0.432 & 7.257 & 48.54 & 0.412 & 6.922 \\
\hline 9 & 49.21 & 0.406 & 6.828 & 50.27 & 0.398 & 6.684 \\
\hline 10 & 50.34 & 0.397 & 6.675 & 51.13 & 0.391 & 6.571 \\
\hline 11 & 49.15 & 0.407 & 6.836 & 47.24 & 0.423 & 7.113 \\
\hline 12 & 48.32 & 0.414 & 6.954 & 48.87 & 0.409 & 6.875 \\
\hline 13 & 51.25 & 0.390 & 6.556 & 50.13 & 0.399 & 6.703 \\
\hline 14 & 50.42 & 0.397 & 6.664 & 48.67 & 0.411 & 6.904 \\
\hline 15 & 49.26 & 0.406 & 6.821 & 48.13 & 0.416 & 6.981 \\
\hline 16 & 48.16 & 0.415 & 6.977 & 47.54 & 0.421 & 7.068 \\
\hline 17 & 48.53 & 0.412 & 6.924 & 49.45 & 0.404 & 6.795 \\
\hline 18 & 47.23 & 0.423 & 7.114 & 48.94 & 0.409 & 6.866 \\
\hline 19 & 49.27 & 0.406 & 6.820 & 50.5 & 0.396 & 6.653 \\
\hline 20 & 49.44 & 0.405 & 6.796 & 50.35 & 0.397 & 6.673 \\
\hline Average & 49.095 & 0.408 & 6.850 & 49.873 & 0.401 & 6.745 \\
\hline
\end{tabular}




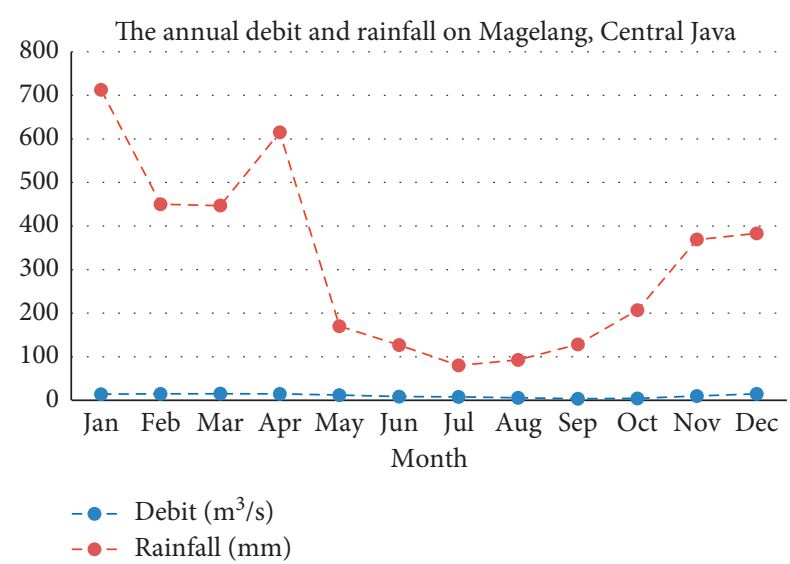

Figure 11: The annual debit and rainfall of Magelang, Central Java, Indonesia.

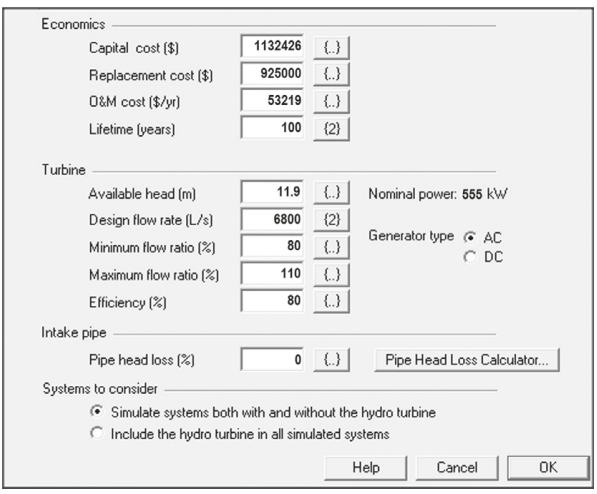

FIgURE 12: The specifications of the micro-hydro system in Homer.

combined with micro-hydro plants, is multilevel, starting from the capacity of $0 \mathrm{~kW}, 10 \mathrm{~kW}, 20 \mathrm{~kW}$, and $30 \mathrm{~kW}$ up to $40 \mathrm{~kW}$. The lifetime of this plant is estimated to be 20 years with a derating factor of $80 \%$. Photovoltaic power plants are fixed, without the use of sunlight tracking controls.

Average monthly solar radiation on horizontal surfaces in Magelang district, Central Java province, Indonesia, was shown in Figure 16, while details of solar radiation on horizontal surfaces are shown in Figure 17. This solar radiation data come from NASA, which are surface meteorology and solar energy for the Magelang region, Central Java. The accuracy of solar radiation data ranges from 6 to $12 \%$. Sunlight radiation in tropical regions such as Indonesia is also relatively stable, so it is assumed that there are no extreme changes.

4.3.2. Design of Battery Bank. In this study, photovoltaic power generation system is designed using a battery bank as a storage of electrical energy. The battery applied in this plant has a nominal voltage of 4 volts with a capacity of $1900 \mathrm{Ah}$. These batteries in the application are connected in series every three batteries to get a 12 -volt voltage because the DC voltage system used is 12 volts. The price of each battery is assumed to be US $\$ 1,444$. Replacement costs are the same as the capital costs because it is assumed that if there is damage

\begin{tabular}{||l|r|}
\hline \multirow{2}{*}{ Month } & Stream Flow \\
\cline { 2 - 3 } & {$[\mathrm{L} / 8]$} \\
\hline January & 6.614 .0 \\
\hline February & 6.470 .0 \\
\hline March & 6.639 .0 \\
\hline April & 6.129 .0 \\
\hline May & 6.018 .0 \\
\hline June & 6.328 .0 \\
\hline July & 6.942 .0 \\
\hline August & 6.627 .0 \\
\hline September & 6.801 .0 \\
\hline Dctober & 6.529 .0 \\
\hline November & 6.699 .0 \\
\hline December & 6.293 .0 \\
\hline Annual average: & 6.507 .8 \\
\hline
\end{tabular}

FIgURE 13: Monthly hydro flow rates in one year at the Ancol Bligo irrigation canal, Magelang, Central Java.

to the battery components, then it must be replaced as a whole.

4.3.3. Design of Power Inverter. A power inverter is a power electronic device that functions to convert DC voltages from solar panels or batteries into AC voltages. The selection of the right power inverter for specific applications adjusts to load requirements. The efficiency of the inverter during operation is around $90 \%$. In Homer applications, the design of a power inverter includes unit size, capital costs, replacement costs, operational and maintenance costs, lifetime, efficiencies, and capacity. The price of a power inverter in Indonesia is US $\$ 2000 / \mathrm{kW}$. Replacement costs are the same as the capital costs. This is due to the assumption that if a fault occurs, then the entire power inverter must be replaced. In this study, the capacity of the power inverter considered is $0 \mathrm{~kW}$ and $40 \mathrm{~kW}$. The design of the power inverter in Homer software was shown in Figure 18.

\subsection{Design of Hybrid Solar Photovoltaic and Micro-Hydro} System. In this study, the design of optimal photovoltaic and micro-hydro solar power plants using Homer software was carried out. Planning, operational, and maintenance simulations are performed by providing input system configuration and component data used. As a result, we made a comparison of parameters that have been determined in the system design. A comparison of these parameters is the cost of capital, cost of selling to the grid, energy costs, and net present costs. The total capital cost is the total costs incurred 

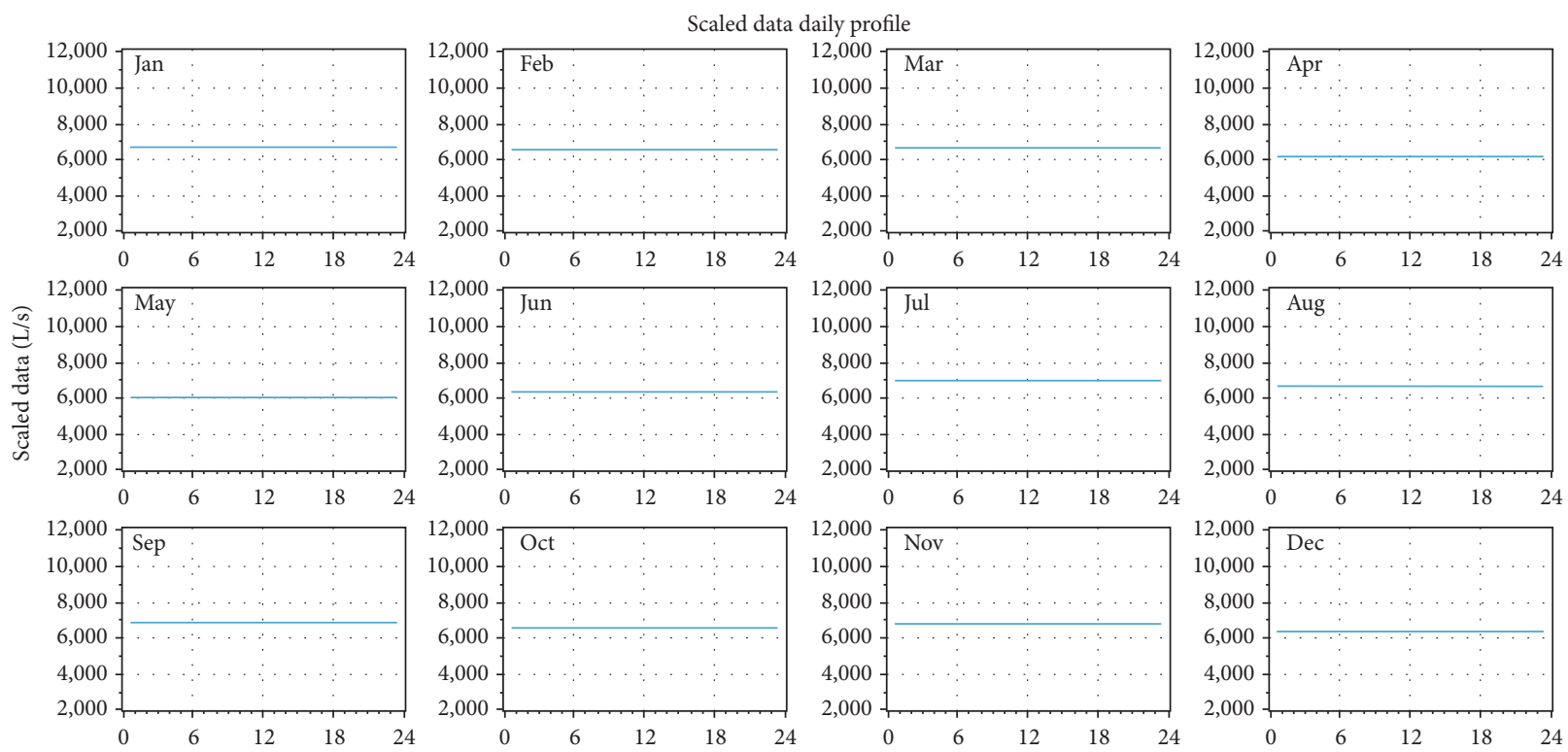

Figure 14: Details of flow rates of every month at the Ancol Bligo irrigation canal, Magelang, Central Java.

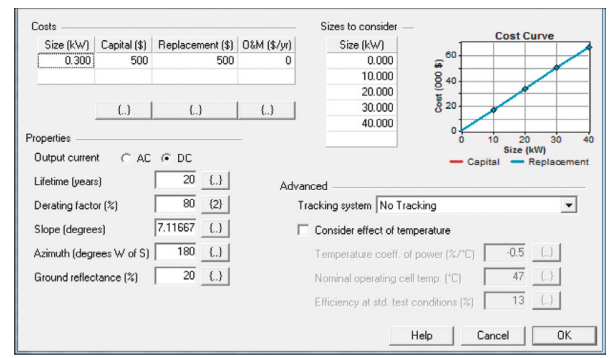

FIGURE 15: The design of the photovoltaic power generation system in Homer software.

\begin{tabular}{|l|r|r|}
\hline Month & $\begin{array}{c}\text { Clearness } \\
\text { Index }\end{array}$ & $\begin{array}{c}\text { Daily Radiation } \\
\text { (kWh/m2/d) }\end{array}$ \\
\hline January & 0.392 & 4.214 \\
\hline February & 0.473 & 5.104 \\
\hline March & 0.547 & 5.751 \\
\hline April & 0.604 & 5.920 \\
\hline May & 0.550 & 4.926 \\
\hline June & 0.543 & 4.605 \\
\hline July & 0.525 & 4.550 \\
\hline August & 0.498 & 4.678 \\
\hline September & 0.464 & 4.720 \\
\hline October & 0.443 & 4.709 \\
\hline November & 0.364 & 3.895 \\
\hline December & 0.384 & 4.095 \\
\hline Average: & 0.478 & 4.761 \\
\hline
\end{tabular}

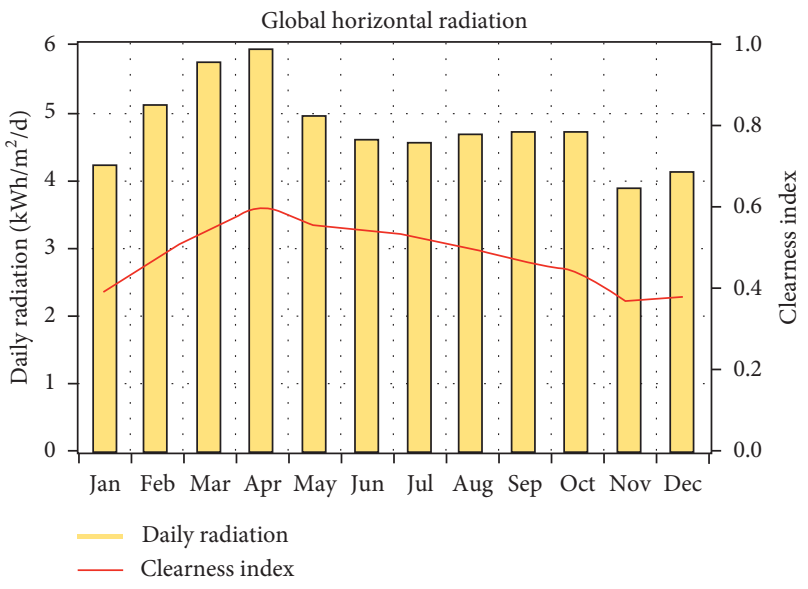

Figure 16: Average monthly solar radiation on horizontal surfaces in Magelang district, Central Java province, Indonesia.

for the implementation of the hybrid power plant construction project. The total cost calculated in this study is the initial cost to build a micro-hydro and PV hybrid power plant. The total capital costs for various hybrid power generation system configurations are shown in Table 3 and Figure 19.
Based on Table 3 and Figure 19, it can be seen that the lowest initial investment cost is the plants with the most straightforward configuration, namely, micro-hydro and grid. The more complex the configuration of the generator, the higher the total capital cost needed. Based on the results, it is also seen that the greater the PV capacity, the higher the 

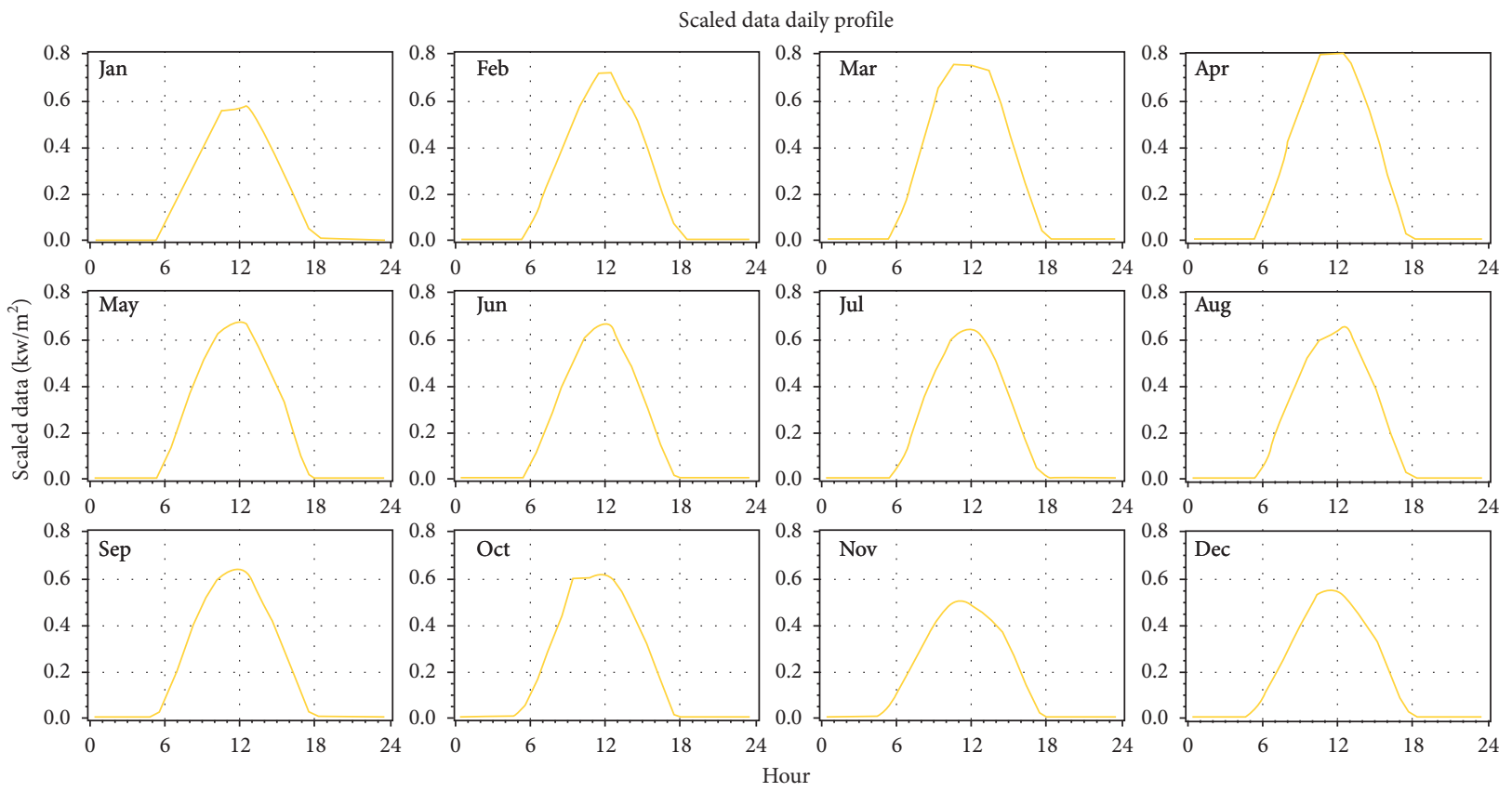

Figure 17: Details of solar radiation on horizontal surfaces in Magelang district, Central Java province, Indonesia.

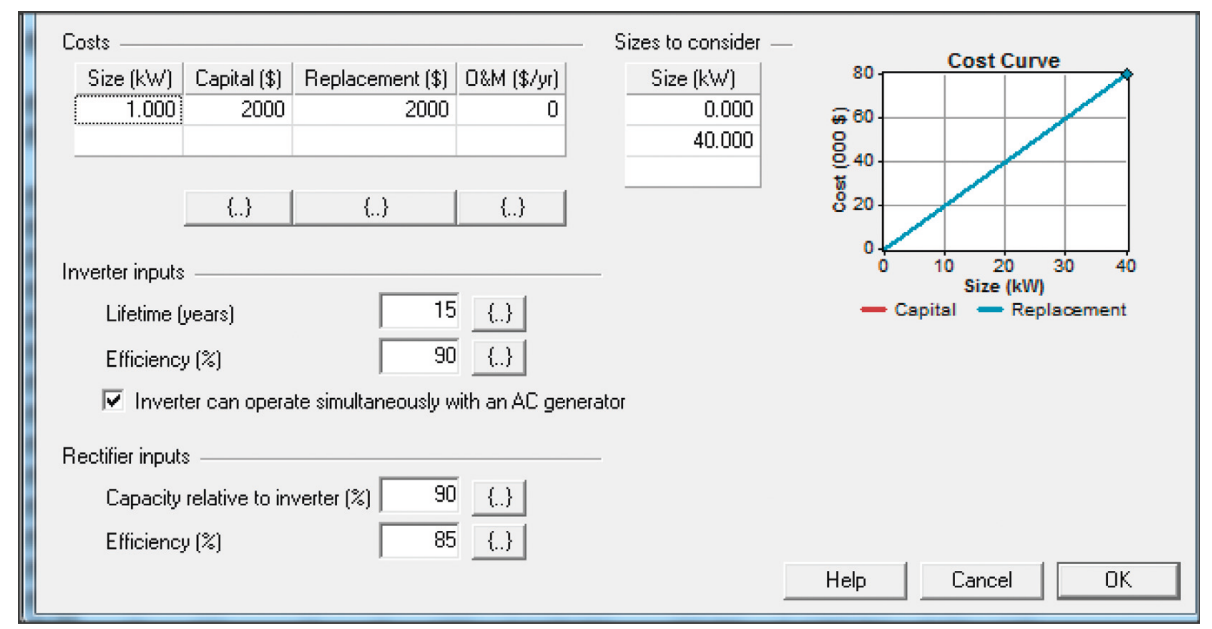

FIgURE 18: The design of the power inverter in Homer software.

TABLE 3: Total capital costs for various configurations of the hybrid solar photovoltaic and micro-hydro systems.

\begin{tabular}{lcc}
\hline Number & $\begin{array}{c}\text { Configuration of hybrid power } \\
\text { plant }\end{array}$ & $\begin{array}{c}\text { Total capital cost (US } \\
\$ \text { ) }\end{array}$ \\
\hline 1 & Grid + micro-hydro & $1,132,426$ \\
2 & Grid + micro-hydro + PV 10 kW & $1,265,076$ \\
3 & Grid + micro-hydro + PV 20 kW & $1,286,371$ \\
4 & Grid + micro-hydro + PV 30 kW & $1,294,443$ \\
5 & Grid + micro-hydro + PV 40 kW & $1,309,537$ \\
\hline
\end{tabular}

investment costs. The lowest total capital cost is for the grid and micro-hydro configuration which is US $\$ 1,132,426$, while the highest total capital cost are for grid, micro-hydro, and PV $40 \mathrm{~kW}$ configurations, which is US $\$ 1,309,537$.
The subsequent analysis is the grid calculation of sales of hybrid power plants. Grid sales are excess electricity, which is when the capacity of a plant exceeds the installed load; this excess energy can then be sent to the grid of state-owned electricity companies. The grid sales for various configurations of the hybrid power plant systems are shown in Table 4 and Figure 20.

Based on Table 4 and Figure 20, it can be seen that the lowest grid sales are the plants with the most straightforward configuration, namely, micro-hydro and grid. The more complex the shape of the generator, the higher the grid sales produced. Based on these results, it can also be seen that the most upper sales grid is in the micro-hydro configuration and $40 \mathrm{~kW} \mathrm{PV}$, which is equal to $4,295,454 \mathrm{kWh} /$ year. However, the difference in the sales grid in the configuration 


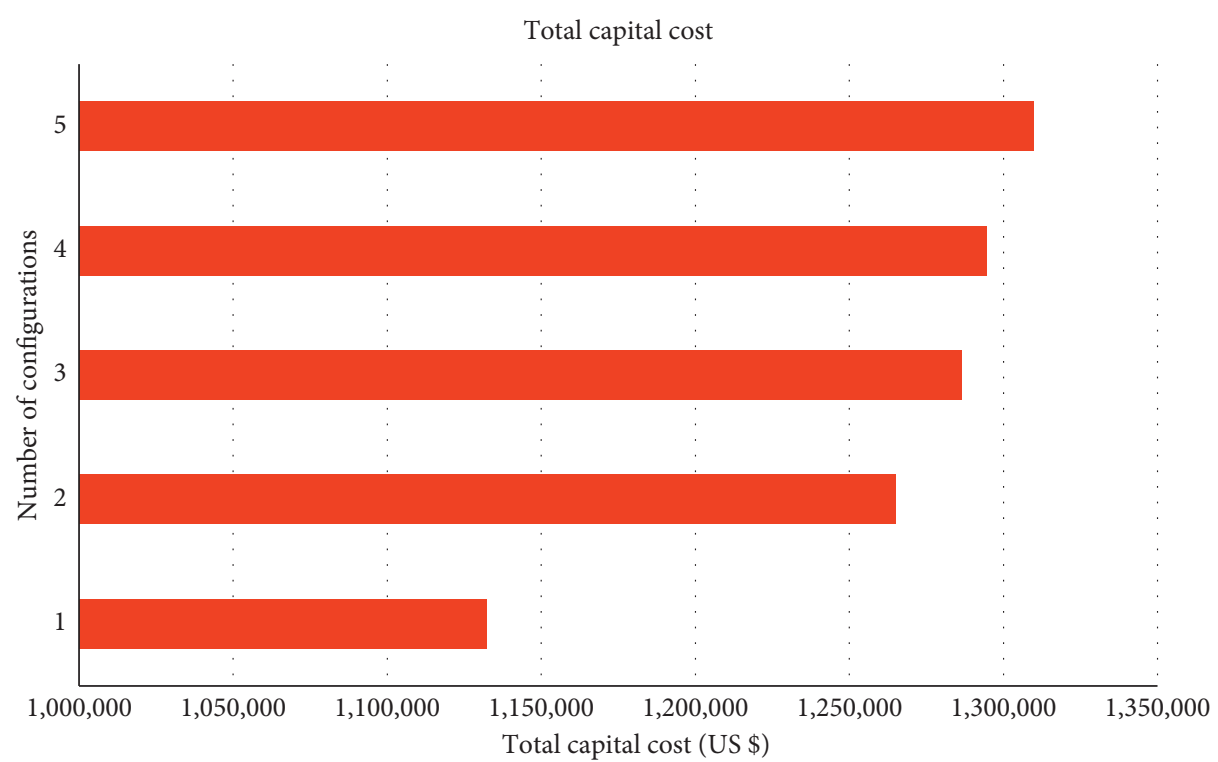

Figure 19: Total capital costs for various configurations of the hybrid solar photovoltaic and micro-hydro systems.

TABLE 4: Grid sales for various configurations of the hybrid power plant systems.

\begin{tabular}{lcc}
\hline Number & Configuration of hybrid power plant & $\begin{array}{c}\text { Grid sales } \\
(\mathrm{kWh} / \mathrm{year})\end{array}$ \\
\hline 1 & Grid + micro-hydro & $3,819,127$ \\
2 & Grid + micro-hydro + PV 10 kW & $3,848,930$ \\
3 & Grid + micro-hydro + PV 20 kW & $3,859,265$ \\
4 & Grid + micro-hydro + PV 30 kW & $3,874,542$ \\
5 & Grid + micro-hydro + PV 40 kW & $3,889,327$ \\
\hline
\end{tabular}

with other configurations is not very significant, because the power produced by PV plants is not so significant compared to micro-hydro plants. This is due to the fact that the majority of the electrical energy produced in this system is generated by micro-hydro plants.

Further analysis is related to the cost of energy (COE). $\mathrm{COE}$ is the average cost of electricity per $\mathrm{kWh}$ of the electrical energy produced by the system. The results of COE calculations for various configurations of the hybrid power plant system are shown in Table 5 and Figure 21.

Based on the results listed in Table 5 and Figure 21, it can be seen that the COE in this study produces a negative number. This negative COE result is caused by the excess energy generated by the hybrid generating system being sold to the grid of state-owned electricity companies. The best COE is produced by the configuration of the micro-hydro generator system without PV, which is US $\$-0.139 / \mathrm{kWh}$.

The subsequent analysis is the net present cost (NPC) parameter. NPC is the current value of all costs that arise during the lifetime minus all income earned during the lifetime. The results of NPC for various configurations of the hybrid power plant system are shown in Table 6 and Figure 22.

The results of NPC in this study produce negative numbers. This is due to the excess energy generated by the hybrid generating system being sold to the grid of state- owned electricity companies. The best NPC produced is made by grid and micro-hydro configuration, which is US $\$-1,732,441$.

Based on an analysis of several parameters for multiple types of hybrid power plant system configurations, the most optimal system is a power plant with a grid and micro-hydro configuration. The optimal system is due to the best optimization of the cost of energy (COE), and net present cost (NPC) is the grid configuration and micro-hydro generation, as shown in the graphs in Figures 21 and 22. COE and NPC values are negative, meaning the excess energy electricity generated by hybrid generators, at a percentage of $76 \%$, is sold to the grid of the state electricity company PLN. The results of the simulation of the optimal power plant system can be seen in Table 7 .

In this optimization, the optimized system is selected based on the lowest NPC. NPC is the current value of all costs that arise during the lifetime minus all income earned during the lifetime. NPC is the essential economic output for the benefit of a system in a generator. Homer software will sort the simulation output data and optimization based on the lowest NPC value.

From the simulation using the Homer software, the results for micro-hydro plants are $4,998,978 \mathrm{kWh} /$ year. The resulting grid purchase is $0 \%$, which means that this system does not buy energy from the grid of state-owned electricity companies. Electricity consumption is $1,179,851 \mathrm{kWh} /$ year or around $24 \%$ of the electrical energy that can be generated by micro-hydro power plants. This configuration produces excess electricity of $3,819,127$ (or 76\%) which will be sold to the grid of state-owned electricity companies, with an average monthly electric power production of $555 \mathrm{~kW}$.

Average monthly electric power production by hybrid power plant systems that can be sold to state-owned electricity companies can be seen in Figure 23. The term renewable fraction is the ratio of renewable energy power plants. In this study, the resulting renewable fraction is 1 , 


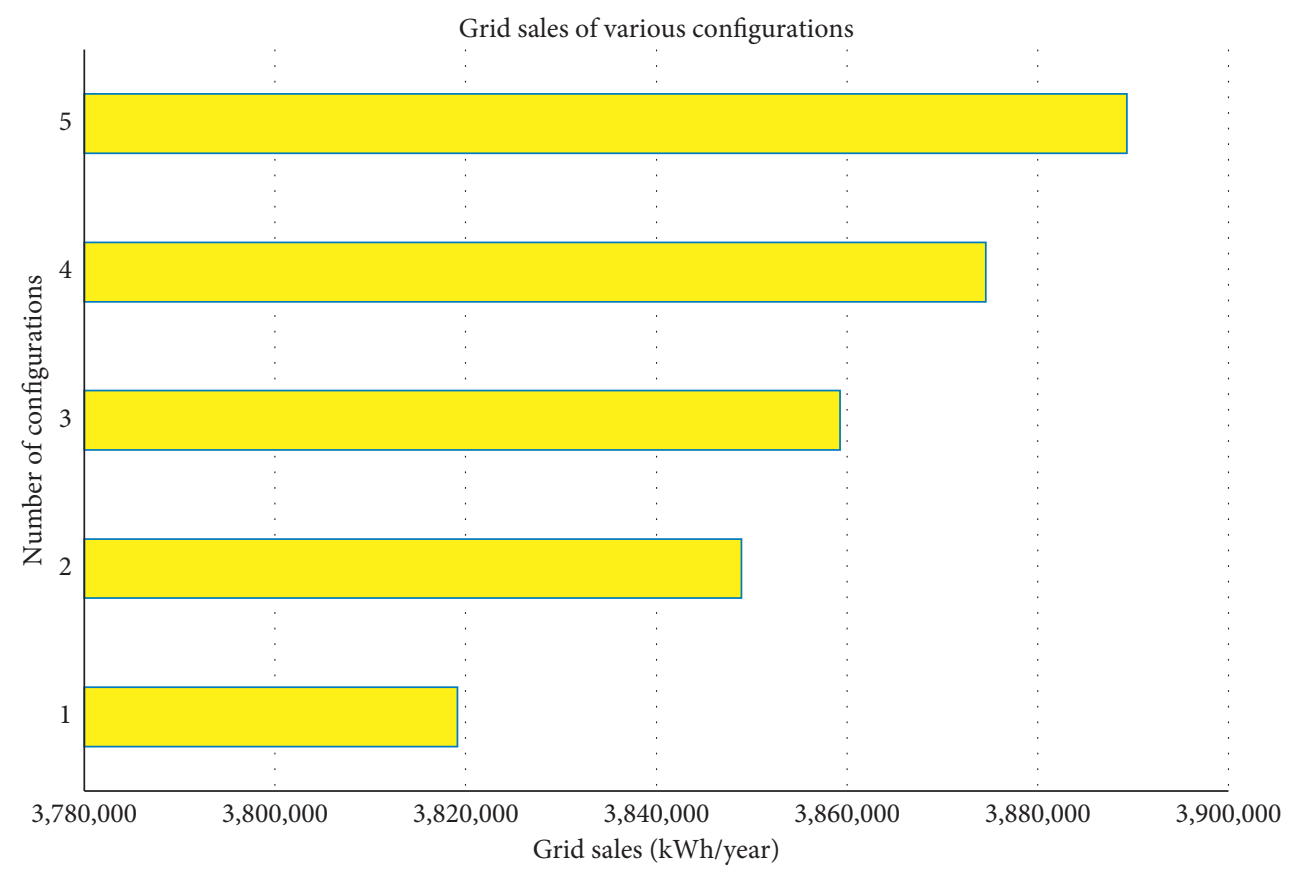

FIgURE 20: Grid sales for various configurations of the hybrid power plant systems.

TABLE 5: COE for various configurations of the hybrid power plant systems.

\begin{tabular}{lcc}
\hline Number & Configuration of hybrid power plant & Cost of energy (US \$/kWh) \\
\hline 1 & Grid + micro-hydro & -0.139 \\
2 & Grid + micro-hydro + PV 10 kW & -0.126 \\
3 & Grid + micro-hydro + PV 20 kW & -0.124 \\
4 & Grid + micro-hydro + PV 30 kW & -0.122 \\
5 & Grid + micro-hydro + PV 40 kW & -0.122 \\
\hline
\end{tabular}

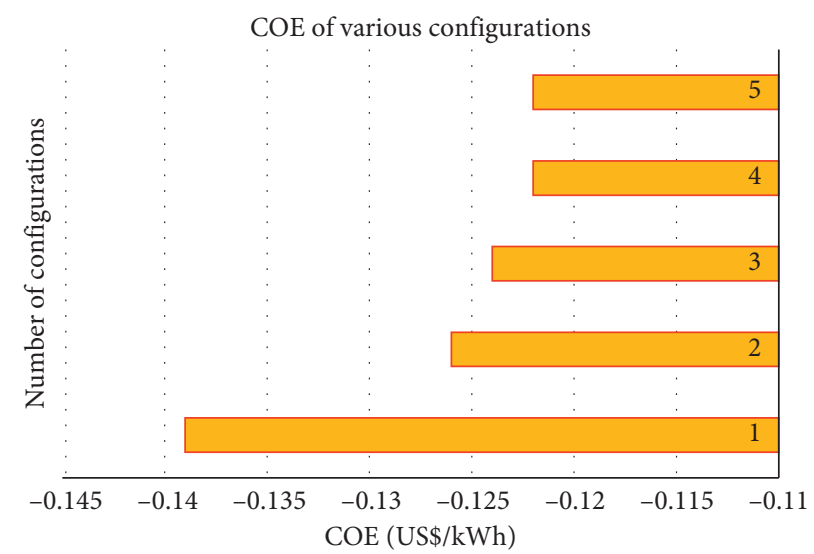

Figure 21: COE for various configurations of the hybrid power plant systems.

TABLE 6: NPC for various configurations of the hybrid power plant systems.

\begin{tabular}{lcc}
\hline Number & Configuration of hybrid power plant & Net present cost (US \$) \\
\hline 1 & Grid + micro-hydro & $-1,732,441$ \\
2 & Grid + micro-hydro + PV 10 kW & $-1,546,092$ \\
3 & Grid + micro-hydro + PV 20 kW & $-1,521,004$ \\
4 & Grid + micro-hydro + PV 30 kW & $-1,518,933$ \\
5 & Grid + micro-hydro + PV 40 kW & $-1,515,277$ \\
\hline
\end{tabular}




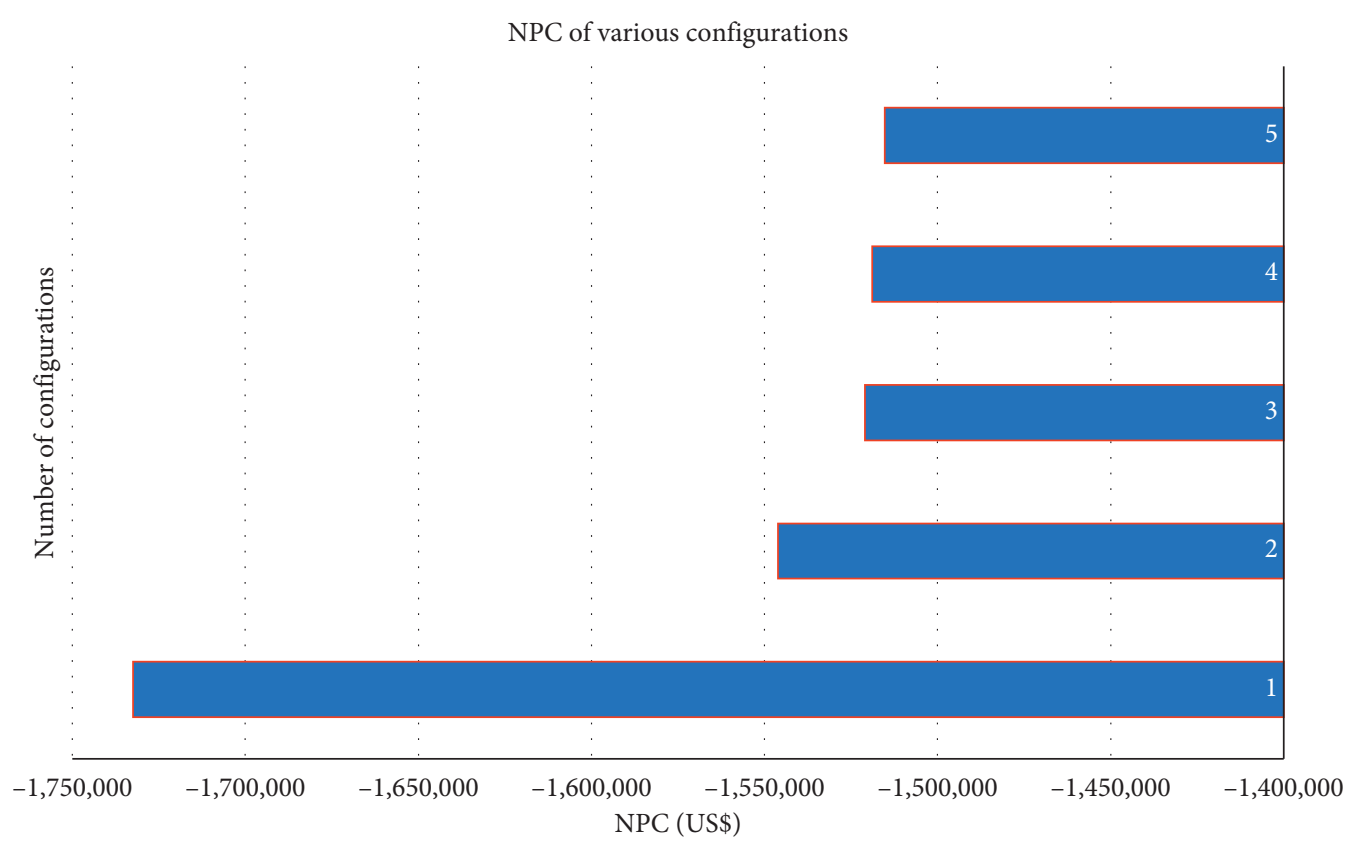

Figure 22: NPC for various configurations of the hybrid power plant systems.

TABle 7: The optimal power plant systems.

\begin{tabular}{lcc}
\hline Number & Optimal parameters & Value \\
\hline 1 & Capacity of PV (kW) & 0 \\
2 & Capacity of micro-hydro (kW) & 555 \\
3 & S4KS25P & 0 \\
4 & Capacity of converter (kW) & 0 \\
5 & Capacity of grid (kW) & 1000 \\
6 & Initial capital (US \$) & $1,132,426$ \\
7 & Operating cost (US \$/year) & $-53,219$ \\
8 & NPC (US \$) & $-1,732,441$ \\
9 & COE (US \$/kWh) & -0.139 \\
10 & Grid sales (kWh/year) & $3,819,127$ \\
11 & Renewable fraction & 1 \\
\hline
\end{tabular}
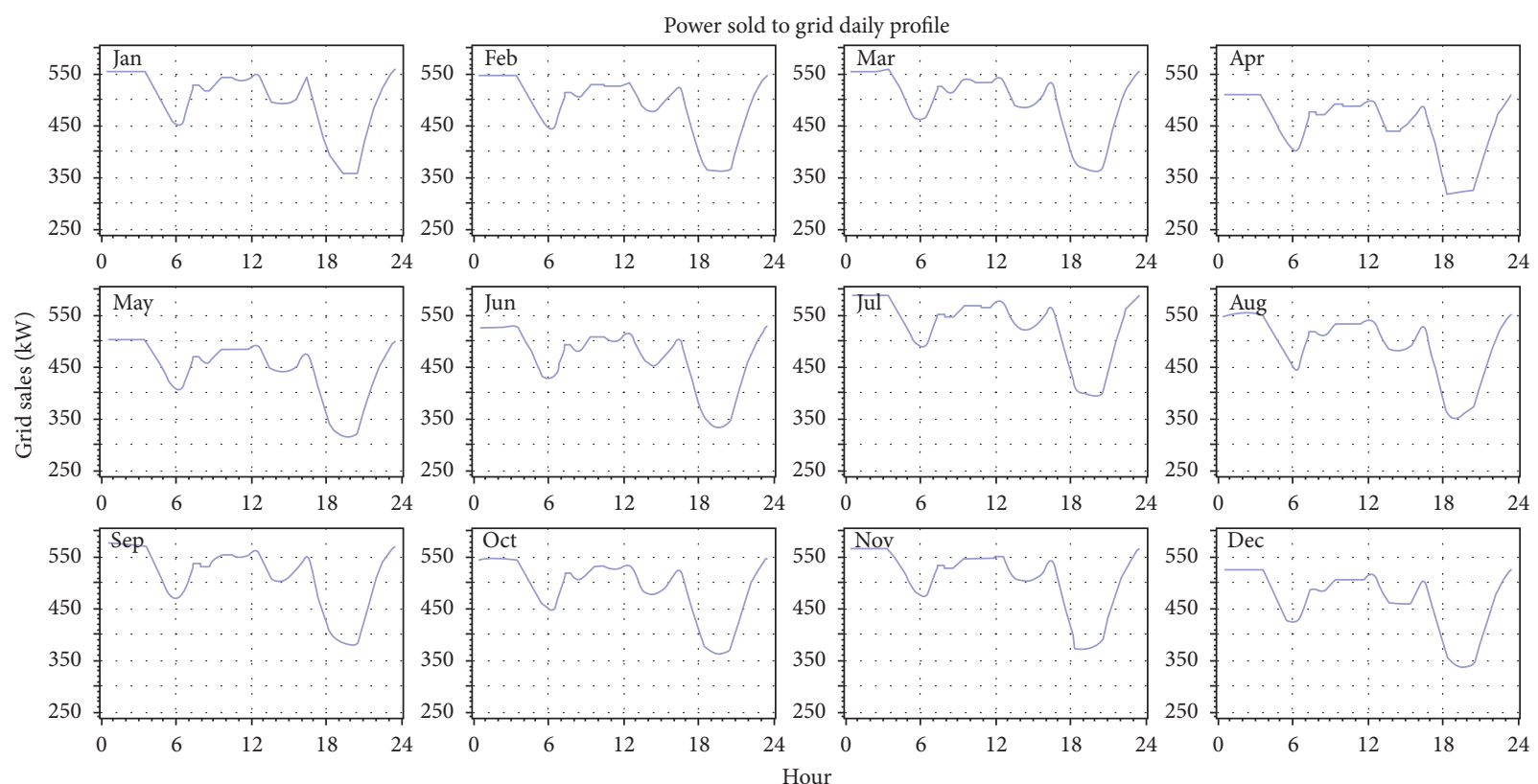

FIGURE 23: Average monthly electric power production by hybrid power plant systems that can be sold to state-owned electricity companies. 
meaning that $100 \%$ of this plant uses renewable energy sources. The average electricity produced by micro-hydro power plants every month reaches $555 \mathrm{~kW}$, and more than half of the power is connected to the grid of state-owned electricity companies.

\section{Conclusions}

Bligo village, Ngluwar district, Magelang regency, Central Java province, Indonesia, has a high potential for renewable energy sources so that it can be used to provide electricity for the surrounding community. The possibility of hydro flow in irrigation canals is quite large, reaching up to $6,800 \mathrm{~L} / \mathrm{s}$ with a head height of $11.9 \mathrm{~m}$ so that it can produce a micro-hydro output power of $555 \mathrm{~kW}$. From the simulation of the hybrid model, which consists of a micro-hydro system that is designed, the production of electrical energy can be used to meet the electrical energy needs for the electricity load of 1023 houses or $3,240 \mathrm{kWh} /$ day, with an average electric load per hour is $135 \mathrm{~kW}$. The electricity produced can also be transmitted to the grid as electrical energy that can be sold to conventional electricity providers, with excess electricity reaching $3,819,127 \mathrm{kWh} /$ year or about $76 \%$ of the power generated by the micro-hydro plant. Meanwhile, the electricity consumption of Bligo village is only $1,179,851 \mathrm{kWh} /$ year or around $24 \%$ of the electrical energy that can be generated by micro-hydropower plants.

\section{Data Availability}

No data were used to support this study.

\section{Conflicts of Interest}

The authors declare that there are no conflicts of interest regarding the publication of this paper.

\section{Acknowledgments}

The authors gratefully acknowledge the contributions of the Directorate General of Development and Research Enhancement, Ministry of Research, Technology and Higher Education of the Republic of Indonesia, for funding this research.

\section{References}

[1] R. A. Al Hasibi, S. P. Hadi, and S. Sarjiya, "Integrated and simultaneous model of power expansion planning with distributed generation," International Review of Electrical Engineering (IREE), vol. 13, no. 2, pp. 116-127, 2018.

[2] H. Hilal, Riza, A. Prastawa, and T. Matsumura, "Turning renewable energy be a dispatchable electric generation through energy management system technology: sumba smart micro grid case," in Proceedings of the Conference on power Engineering and renewable energy (ICPERE), pp. 29-31, Solo, Indonesia, October 2018.

[3] Erinofiardi, P. Gokhale, A. Date et al., "A review on micro hydropower in Indonesia," Energy Procedia, vol. 110, pp. 316-321, 2017.
[4] A. M. Fathoni, N. A. Utama, and M. A. Kristianto, “A technical and economic potential of solar energy application with feed-in tariff policy in Indonesia," Procedia Environmental Sciences, vol. 20, pp. 89-96, 2014.

[5] R. Syahputra, I. Robandi, and M. Ashari, "Performance improvement of radial distribution network with distributed generation integration using extended particle swarm optimization algorithm," International Review of Electrical Engineering (IREE), vol. 10, no. 2, pp. 293-304, 2015.

[6] R. Syahputra, I. Soesanti, and M. Ashari, "Performance enhancement of distribution network with DG integration using modified PSO algorithm," Journal of Electrical Systems (JES), vol. 12, no. 1, pp. 1-19, 2016.

[7] U. K. Kalla, B. Singh, S. S. Murthy, C. Jain, and K. Kant, "Adaptive sliding mode control of standalone single-phase microgrid using hydro, wind, and solar PV array-based generation," IEEE Transactions on Smart Grid, vol. 9, no. 6, pp. 6806-6814, 2018.

[8] K. Kusakana, J. L. Munda, and A. A. Jimoh, "Feasibility study of a hybrid PV-micro hydro system for rural electrification," in Proceedings of the IEEE AFRICON 2009, vol. 23-25, Nairobi, Kenya, September 2009.

[9] G. Brusco, A. Burgio, D. Menniti, A. Pinnarelli, and N. Sorrentino, "Optimal sizing of DGs for a CHP-based agroindustrial microgrid with a priority criteria operational strategy," International Review of Electrical Engineering (IREE), vol. 9, no. 2, pp. 351-362, 2014.

[10] J. Ahmed and Z. Salam, "An enhanced adaptive P\&O MPPT for fast and efficient tracking under varying environmental conditions," IEEE Transactions on Sustainable Energy, vol. 9, no. 3, pp. 1487-1496, 2018.

[11] H. A. Sher, K. E. Addoweesh, and K. Al-Haddad, "An efficient and cost-effective hybrid MPPT method for a photovoltaic flyback microinverter," IEEE Transactions on Sustainable Energy, vol. 9, no. 3, pp. 1137-1144, 2018.

[12] L. Tang, W. Xu, and C. Mu, "Analysis for step-size optimisation on MPPT algorithm for photovoltaic systems," IET Power Electronics, vol. 10, no. 13, pp. 1647-1654, 2017.

[13] R. Syahputra, R. O. Wiyagi, and Sudarisman, "Performance analysis of a wind turbine with permanent magnet synchronous generator," Journal of Theoretical and Applied Information Technology (JATIT), vol. 95, no. 9, pp. 1950-1957, 2017.

[14] M. Hauck, A. Rumeau, A. I. Bratcu, S. Bacha, I. Munteanu, and D. Roye, "Identification and control of a river-currentturbine generator-application to a full-scale prototype," IEEE Transactions on Sustainable Energy, vol. 9, no. 3, pp. 1365-1374, 2018.

[15] L. Wang, S.-J. Chen, S.-R. Jan, and H.-W. Li, "Design and implementation of a prototype underwater turbine generator system for renewable microhydro power energy," IEEE Transactions on Industry Applications, vol. 49, no. 6, pp. 2753-2760, 2013.

[16] H. Patel and S. Chowdhury, "Cost effective microhydro-based microgrid schemes for rural electrification in South Africa," in Proceedings of the 53rd International Universities Power Engineering Conference (UPEC), pp. 1-6, Glasgow City, UK, September 2018.

[17] M. Younas, R. Kamal, M. S. Khalid, and A. Qamar, "Economic planning for remote community microgrid containing solar PV, biomass gasifier and microhydro," in Proceedings of the Clemson University Power Systems Conference (PSC), pp. 1-7, Charleston, SC, USA, September 2018. 
[18] A. Z. Amin, D. Gielen, D. Saygin, and J. Rigter, "Renewable energy prospects: Indonesia, a REmap analysys," in Proceedings of the International Renewable Energy Agency (IRENA), Abu Dhabi, UAE, March 2017.

[19] M. Suri, T. Cebecauer, N. Suriova et al., "Solar resource and photovoltaic power potential of Indonesia," in Renewable Energy Resource Mapping And Geospatial Planning-Indonesia, World Bank Group, Global ESMAP Initiative, Bratislava, Slovakia, 2017.

[20] A. Liebman, "Indonesia: a nation rich in unrealized solar energy potential," Solar Magazine, 2019.

[21] M. A. Ghasemi, A. Ramyar, and H. Iman-Eini, "MPPT method for PV systems under partially shaded conditions by approximating I-V curve," IEEE Transactions on Industrial Electronics, vol. 65, no. 5, pp. 3966-3975, 2018.

[22] B.-R. Peng, K.-C. Ho, and Y.-H. Liu, "A novel and fast MPPT method suitable for both fast changing and partially shaded conditions," IEEE Transactions on Industrial Electronics, vol. 65, no. 5, pp. 3240-3251, 2018.

[23] R. Syahputra and I. Soesanti, "Power System Stabilizer model based on Fuzzy-PSO for improving power system stability," in Proceedings of the 2015 International Conference on Advanced Mechatronics, Intelligent Manufacture, and Industrial Automation (ICAMIMIA), pp. 121-126, Surabaya, Indonesia, October 2015.

[24] M. K. Hossain and M. H. Ali, "Overview on maximum power point tracking (MPPT) techniques for photovoltaic power systems," International Review of Electrical Engineering (IREE), vol. 8, no. 4, pp. 1363-1378, 2013.

[25] J. C. Y. Hui, A. Bakhshai, and P. K. Jain, “A sensorless adaptive maximum power point extraction method with voltage feedback control for small wind turbines in off-grid applications," IEEE Journal of Emerging and Selected Topics in Power Electronics, vol. 3, no. 3, pp. 817-828, 2015.

[26] B. Römer, Y. Julliard, R. Fauzianto, M.-J. Poddey, and I. Rendroyoko, "Pioneering smart grids for Indonesia - the case of a smart grid roadmap development," CIRED-Open Access Proceedings Journal, vol. 2017, no. 1, pp. 2484-2487, 2017.

[27] H. Setiadi, N. Mithulananthan, R. Shah, T. Raghunathan, and T. Jayabarathi, "Enabling resilient wide-area POD at BESS in Java, Indonesia $500 \mathrm{kV}$ power grid," IET Generation, Transmission \& Distribution, vol. 13, no. 16, pp. 3734-3744, 2019.

[28] M. Metry, M. B. Shadmand, R. S. Balog, and H. Abu-Rub, "MPPT of photovoltaic systems using sensorless currentbased model predictive control," IEEE Transactions on Industry Applications, vol. 53, no. 2, pp. 1157-1167, 2017.

[29] A. Asgharzadeh, B. Marion, C. Deline, C. Hansen, J. S. Stein, and F. Toor, "A sensitivity study of the impact of installation parameters and system configuration on the performance of bifacial PV arrays," IEEE Journal of Photovoltaics, vol. 8, no. 3, pp. 798-805, May 2018.

[30] A. Arguello, J. D. Lara, J. D. Rojas, and G. Valverde, "Impact of rooftop PV integration in distribution systems considering socioeconomic factors," IEEE Systems Journal, vol. 12, no. 4, pp. 3531-3542, 2018. 


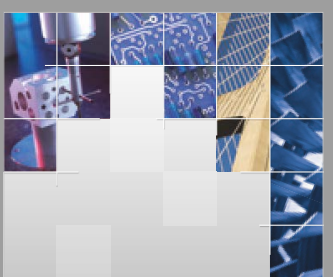

\section{Enfincering}
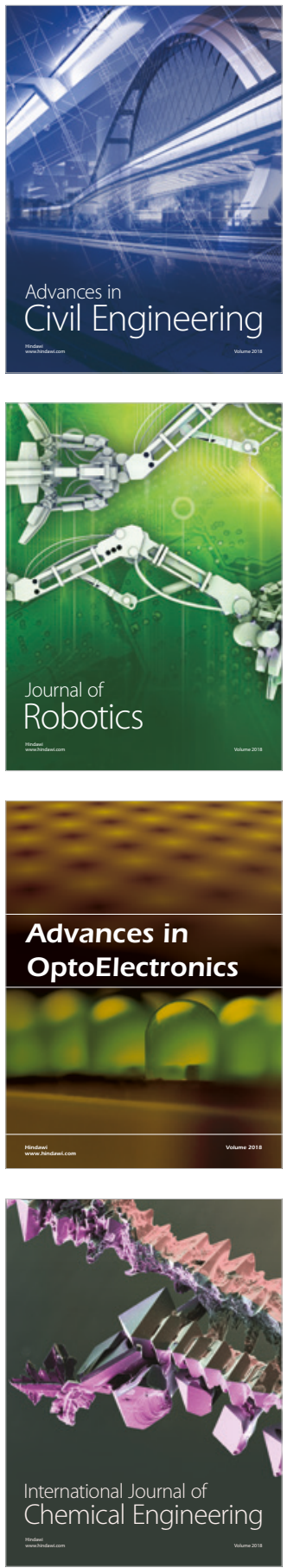

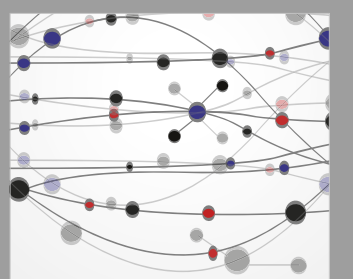

\section{Rotating \\ Machinery}

The Scientific World Journal

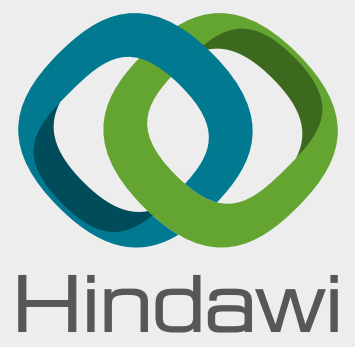

Submit your manuscripts at

www.hindawi.com
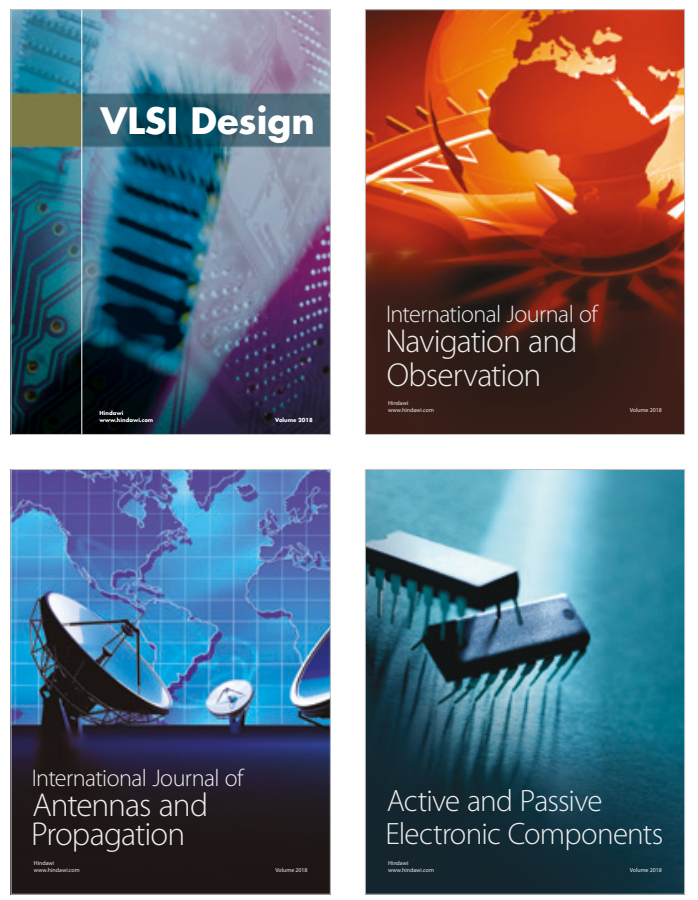
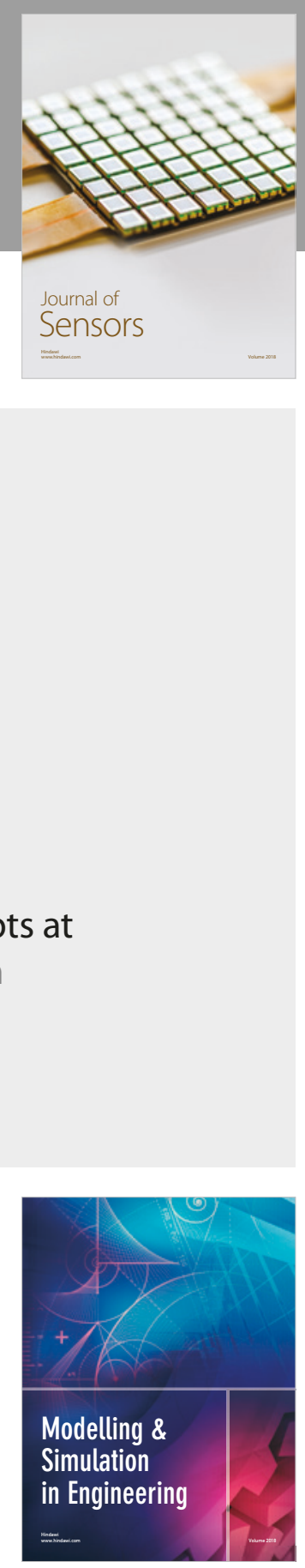

\section{Advances \\ Multimedia}
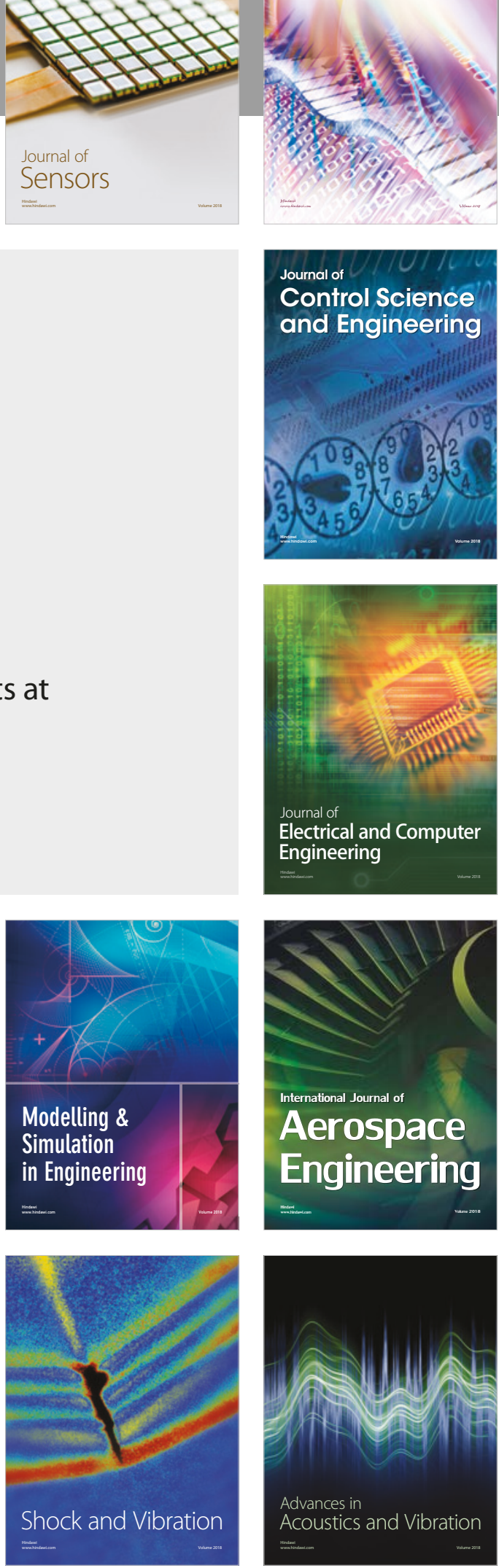